University of Nebraska - Lincoln

DigitalCommons@University of Nebraska - Lincoln

USGS Staff -- Published Research

US Geological Survey

2015

Bioaccumulation of Stentorin, the Probable Causative Agent for Discolored ("Purple") Eggs and Ovaries in Blue Catfish (Ictalurus furcatus) from Eufaula Lake, Oklahoma, USA

Robert W. Gale

U.S. Geological Survey, Columbia Environmental Research Center, Columbia, Missouri

Diana M. Papoulias

U.S. Geological Survey, Columbia Environmental Research Center, Columbia, Missouri

Christopher J. Schmitt

U.S. Geological Survey, Columbia Environmental Research Center, Columbia, Missouri, cjschmitt@usgs.gov

Follow this and additional works at: http://digitalcommons.unl.edu/usgsstaffpub

Gale, Robert W.; Papoulias, Diana M.; and Schmitt, Christopher J., "Bioaccumulation of Stentorin, the Probable Causative Agent for Discolored ("Purple") Eggs and Ovaries in Blue Catfish (Ictalurus furcatus) from Eufaula Lake, Oklahoma, USA" (2015). USGS Staff -Published Research. 875.

http:// digitalcommons.unl.edu/usgsstaffpub/875

This Article is brought to you for free and open access by the US Geological Survey at DigitalCommons@University of Nebraska - Lincoln. It has been accepted for inclusion in USGS Staff -- Published Research by an authorized administrator of DigitalCommons@University of Nebraska - Lincoln. 


\title{
Bioaccumulation of Stentorin, the Probable Causative Agent for Discolored ("Purple") Eggs and Ovaries in Blue Catfish (Ictalurus furcatus) from Eufaula Lake, Oklahoma, USA
}

\author{
Robert W. Gale,* Diana M. Papoulias, and Christopher J. Schmitt \\ U.S. Geological Survey, Columbia Environmental Research Center, Columbia, Missouri 65201-8709, United States
}

Supporting Information

\begin{abstract}
Observations of reddish to "purple" discolored eggs in the ovaries of adult female blue catfish (Ictalurus furcatus) from the northern arm of Eufaula Lake, a eutrophic multiuse impoundment in east-central Oklahoma, were first reported in 2006. Blue catfish eggs are normally cream to light yellow. Reports peaked in 2007-2008 and declined through 2009-2010; purple eggs have not been reported between 2010 and 2014. In the laboratory, all tissues and fluids of affected fish were strongly orange-red fluorescent under UV illumination, with the fluorescence most apparent in the lipid-rich ovaries and eggs. The causative agent was isolated chromatographically and confirmed by mass spectrometry as stentorin $(1,3,4,6,8,10,11,13-$

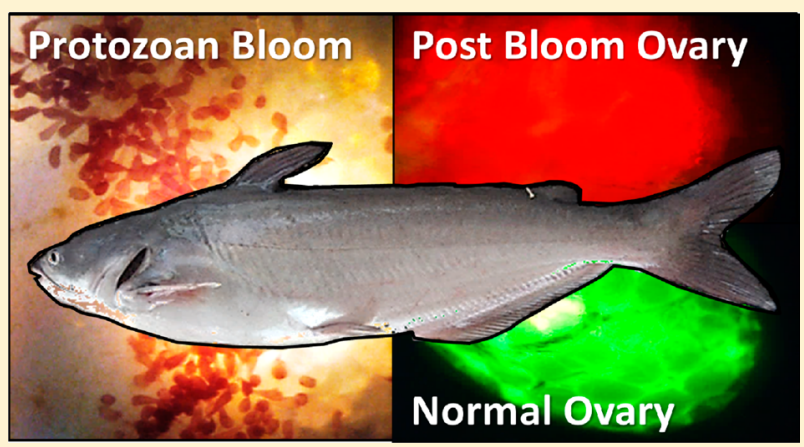
octahydroxy-2,5-diisopropyl-phenanthro[ $[1,10,9,8, \mathrm{o}, \mathrm{p}, \mathrm{q}, \mathrm{r}, \mathrm{a}]$ perylene-7,14-dione), the fluorescent, lipophilic pigment associated with the photoreceptor protein of the ciliated protozoan Stentor coeruleus (Heterotrichea; Stentoridae). Larval medaka (Orizias latipes) readily consumed S. coeruleus in the laboratory and were observed to fluoresce in the same manner as the affected blue catfish. Potential deleterious effects of stentorin bioaccumulation remain to be determined, as do the geographic extent and the identities of other fluorescent compounds isolated from catfish eggs and ovaries.
\end{abstract}

\section{INTRODUCTION}

The blue catfish (Ictalurus furcatus; henceforth, catfish) is an apex predator that supports a valuable sport fishery in Eufaula Lake (EL), Oklahoma (Figure S1). ${ }^{1}$ In May 2006, discolored ("purple") eggs were reported to be widespread and observed in about $25 \%$ of female catfish from the northern arm of EL, upstream from Lake Eufaula [Fountainhead] State Park (R. Miller, formerly at Conner State University and G. Wright, Okla. Wildlife Dept.). Fish that presented with purple eggs were otherwise clinically normal (Figure 1). Additional female catfish with discolored ovaries were reported in the North Canadian arm in 2006; unconfirmed reports of affected fish continued through August. The purple coloration was not as intense in 2007-2008, only a few fish presenting discolored eggs were reported in 2009-2010, and none were reported between 2010 and 2014 .

Eufaula Lake is a large multiuse impoundment on the Canadian River in east-central Oklahoma [surface area 41278 ha $\left(412 \mathrm{~km}^{2}\right)$; shoreline length, $1300 \mathrm{~km}$; storage capacity, 2.6 billion $\mathrm{m}^{3}$; drainage area, $123081 \mathrm{~km}^{2}$; mean depth, $6.7 \mathrm{~m}$; maximum depth, $26.5 \mathrm{~m}$; water temperature, $4.5-31{ }^{\circ} \mathrm{C}$; average renewal time, $1.35 \mathrm{y}$; maximum renewal time, $3.49 \mathrm{y}$; stratification (dependent on location), 5-12 m; anoxic below thermocline during the summer $]^{1}$ managed by the U.S. Army Corps of Engineers (Figure S1). The North Canadian and Deep Fork rivers drain agricultural lands that feed the eutrophic northern arm of EL. Additional pollution sources within the watershed of the northern arm identified as potential causes of the discolored eggs include: (1) a smelter in Henryetta, Okla. located in the watershed of a tributary to the Deep Fork River is a source of zinc, arsenic, cadmium, and lead. Some of these metals are known to affect heme synthesis in fish. ${ }^{2,3}$ (2) A facility in Okmulgee, OK produces polysaccharide xanthan gum (a food additive) via Xanthomonas campestris fermentation of cabbage; it previously manufactured gellan gum (a gelling agent and food additive) via Pseudomonas elodea fermentation of red seaweed. This facility was cited for effluent violations in 2005$2006^{4}$ and was considered to be a potential source of nutrients and plant pigments. (3) A municipal wastewater treatment plant (WWTP) that received effluent from the xanthan gum facility until 2003 and exceeded discharge limits frequently beginning in 1996. An April-June 2000 sewage release from the WWTP caused a massive fish kill along $17.6 \mathrm{~km}$ of the Deep Fork River about $32 \mathrm{~km}$ upstream of the inflow to the northern arm of EL. ${ }^{5}$ This was the area from which catfish with discolored eggs were most frequently reported.

Received: March 19, 2015

Revised: July 10, 2015

Accepted: July 16, 2015

Published: July 31, 2015 

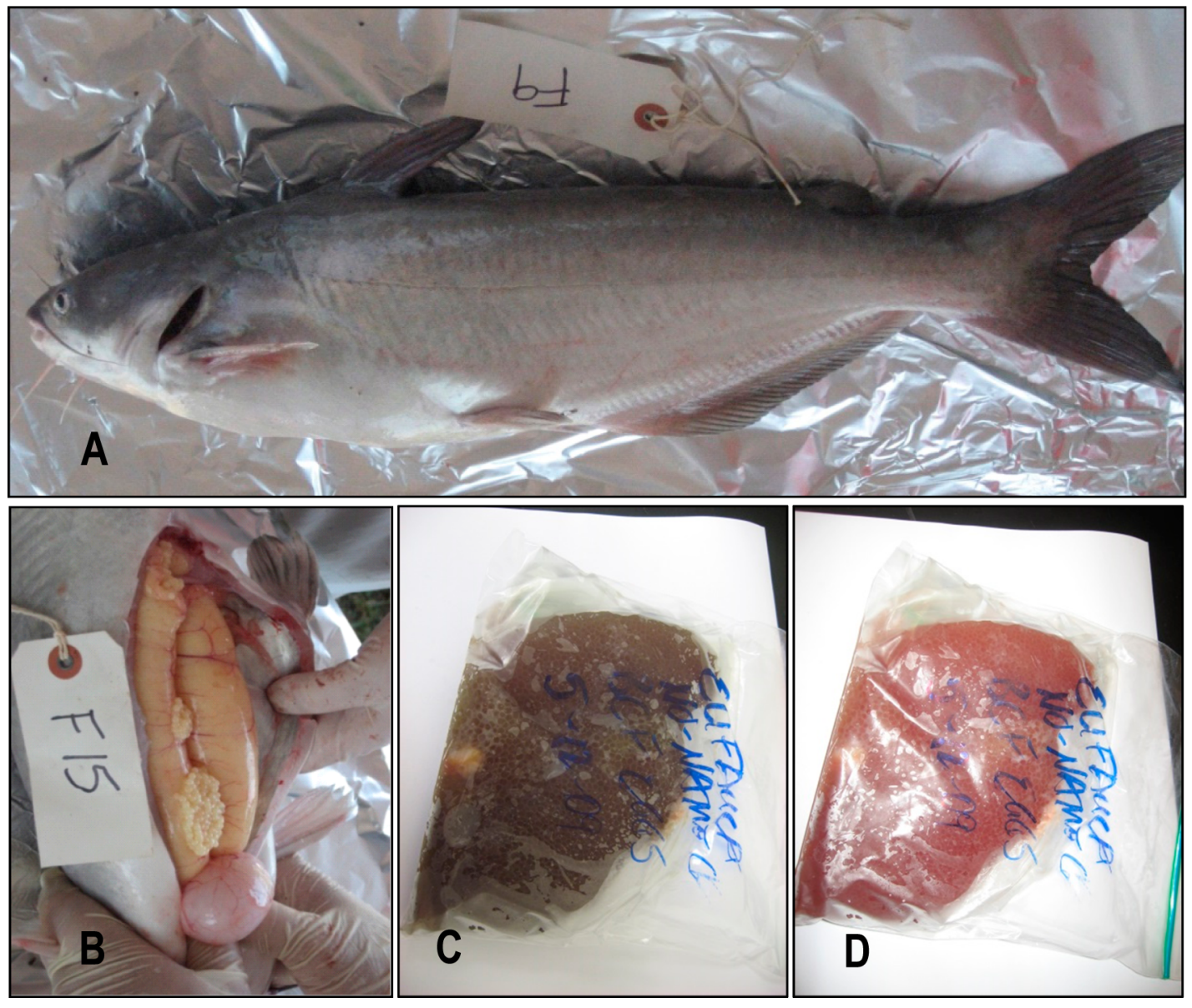

Figure 1. (A) Adult blue catfish (Ictalurus furcatus) from Eufaula Lake, (B) 2009-normal eggs and ovaries, (C) 2009-discolored ovary with eggs (no flash), and (D) 2009-discolored ovary with eggs (flash).

Initial (2006) concerns focused on public health and potential deleterious effects on regionally important sport fisheries at EL. Normal catfish ovaries range in color from white to yellow (Figure 1); however, coloration can be induced with natural and artificial food colorants, disease, and chemical exposure. ${ }^{6}$ Past and present industrial activity in the northern portion of the EL watershed as well as reported fish kills and elevated levels of heavy metals in sediments and water ${ }^{7-9}$ increased suspicion that the purple coloration was related to anthropogenic activity. However, preliminary screening of male and female catfish (with and without discolored eggs) collected from the northern arm of EL indicated only low tissue concentrations of metals, organochlorine pesticides, and polychlorinated biphenyls (Table S1 and Table S2). This shifted our attention toward potential alternative causes for the purple color.

Our objectives were to isolate, characterize, and identify the causative agent(s) responsible for the egg and ovary discoloration as a first step toward determining whether concern for the health of human fish consumers and the fisheries was warranted. We report here that the probable causative agent is stentorin $(1,3,4,6,8,10,11,13$-octahydroxy-2,5diisopropyl-phenanthro[1,10,9,8,o,p,q,r,a] perylene-7,14-dione), the blue-green pigment associated with the photoreceptor protein of the ciliated protozoan Stentor coeruleus (Heterotrichea; Stentoridae).

\section{EXPERIMENTAL SECTION}

Fish Collection. Only two samples exhibiting discolored ovaries containing eggs were available for study. The first sample was a female catfish with purple discolored ovaries containing eggs received for examination in May-June 2006; a male catfish without observable purple discoloration was also received for comparison and was evaluated. The second sample consisted of discolored ovaries containing eggs (from a blue catfish) received in May 2009 by state personnel from an anonymous local angler. These samples were collected from the northern arm of EL. Samples were shipped frozen on ice and stored at $-20{ }^{\circ} \mathrm{C}$. Tissues (liver, ovaries containing eggs, gastrointestinal tracts) from eight additional females with discolored eggs, five females with normal eggs, an immature female, and an individual of indeterminate sex were collected from the northern arm of EL in 2006-2007 by volunteers via angling and were preserved in $10 \%$ neutral buffered formalin. This preservation method was later found to gradually remove any purple or gray-green color or fluorescence originally present.

In June 2009, 23 female catfish, all found to have either normal ovaries containing eggs or spent ovaries, were collected from EL via pulsed-DC electrofishing by federal personnel. Fish were grossly examined and processed for tissue collection ${ }^{10}$ then shipped on ice for gross and microscopic evaluation. Four gravid female catfish also were obtained via electrofishing from the Missouri River (MR) near Boonville, Missouri, in June 2011 by U.S. Fish and Wildlife Service personnel. The ovaries were removed, divided, and either frozen or placed in neutral- 
buffered formalin. These fish were visually examined for comparison with the two sets of discolored ovaries containing eggs from EL.

Visual and Microscopic Techniques. Tissues used for gross and microscopic examination and chemical analysis were removed after partially thawing the fish (to minimize exposure and potential degradation of any colored and fluorescent components) and the tissues; fish were refrozen within $10 \mathrm{~min}$ after dissection. Frozen tissues were cut with a scalpel under air, nitrogen, and in citric acid and observed for color changes. Initial characterization involved gross examinations using a hand-held UV light (model UVSL-14P, UVP LLC, Upland, CA) with short $(254 \mathrm{~nm})$ and long $(365 \mathrm{~nm})$ wavelength excitation.

Microscopic examinations of tissues utilized a Nikon SMZ dissecting microscope with epifluorescence (Nikon Instruments Inc., Melville, NY). Frozen or thawed tissues and organs were observed at 7.5-112.5× under dark field illumination with white light or fluorescence with mirror cube units using blue excitation (excitation, GFPLP 450-490 nm dichroic; emission, 495DCLP 500-1200 nm LP) or green excitation (excitation, TRI-TC DS-Red 530-560 nm dichroic; emission, 570DCLP 590-650 nm) with a 515-555 nm bandpass filter.

Formalin-preserved normal and discolored ovaries from 2006 to 2007 were prepared following standard and routine procedures. $^{10}$ Tissues were embedded in paraffin; $7 \mu \mathrm{m}$ sections were prepared and stained with hemotoxylin and eosin. Tissues were viewed using a Nikon 90i compound microscope with epifluorescence.

Chemical Techniques. Of the two available samples of discolored catfish exhibiting discolored (purple) ovaries with eggs, the 2006 female was selected for comprehensive chemical analysis of the colored component(s). Tissues selected for analysis included the ovaries containing eggs and external mucus with residual blood. The colored component was later confirmed in the 2009 discolored ovary with eggs. The following tissues were analyzed for comparison: lipid-rich tissues and mucus with residual blood from the 2006 adult male (lacking visible purple discoloration); normal ovaries containing eggs or the spent ovaries from the 2009 collection from EL and the 2011 collection from MR.

Tissues (approximately $10 \mathrm{~g}$ ) or fluids (approximately 25 $\mathrm{mL}$ ) were homogenized and extracted with acetone $(50 \mathrm{~mL})$. The wet acetone extract was centrifuged, and the supernatant was removed and evaporated under nitrogen. The remaining aqueous phase and precipitate were removed, and the colored and fluorescent components of interest (adhering to the centrifuge tube wall) were washed 4 times with $20 \mathrm{~mL}$ of water and dried under nitrogen. These components were solubilized in hexane $(5 \mathrm{~mL})$, partitioned against $5 \mathrm{~mL}$ of water 4 times to remove polar constituents, and dried over anhydrous sodium sulfate. The components were next partitioned from hexane into methanol $(5 \mathrm{~mL})$, and the methanol solution was partitioned against $5 \mathrm{~mL}$ of hexane 4 times to remove nonpolar constituents.

The ultraviolet-visible (UV-V) absorption spectra of 1-, 10 -, and 100 -fold dilutions of $1 \mathrm{~g} / \mathrm{mL}$ (tissue) or $1 \mathrm{~mL} / \mathrm{mL}$ (fluids) solutions of the extracts in methanol were acquired from $200-800 \mathrm{~nm}(600 \mathrm{~nm} / \mathrm{min}, 1 \mathrm{~cm}$ cell $)$ using a DU-640 spectrophotometer (Beckman-Coulter, Inc., Fullerton, CA). Similarly, fluorescence excitation and emission spectra were acquired from 200-800 $\mathrm{nm}$ (depending on excitation wavelength, and $\Delta \lambda$ of $25 \mathrm{~nm}$ for synchronous scanning, $1 \mathrm{~cm}$ cell) using a LS-50B luminescence spectrometer (PerkinElmer, Inc., Waltham, MA). UV-V spectra of extracts at $\mathrm{pH} 2$ and 10 (adjusted with $0.1 \mathrm{~N} \mathrm{HCl}$ and $0.1 \mathrm{~N} \mathrm{NaOH}$, respectively) were also acquired.

Protein binding of the components was explored by native polyacrylamide gel electrophoresis (PAGE) performed with $1 \times$ Cellytic B protein extractions (in 0.1 M ZPS $\mathrm{pH}$ 6.5) of tissues. The extracts were separated by non-SDS-DTT native discontinuous PAGE (Bio-Rad Ready Gel 12\%, 12 well, 2× native sample loading buffer, $25 \mathrm{mM}$ tris, and $192 \mathrm{mM}$ glycine running buffer $\mathrm{pH} 8.3$ ).

Reversed-phase high-performance liquid chromatography (HPLC) utilized a $\mathrm{C}_{8}$ guard column and column (Beta-Basic $\mathrm{C}_{8} 100 \AA 5 \mu \mathrm{m} 100 \times 4.6 \mathrm{~mm}$, Thermo Fisher Scientific, Waltham, MA). Either an 1100 Series HPLC system with UV$\mathrm{V}$ and fluorescence detectors (Agilent Technologies, Santa Clara, CA) or a Surveyor HPLC system with photodiode array detector (Thermo Scientific, Waltham, MA) was used. After optimization, the UV-V detector of the 1100 Series system was scanned from 250 to $650 \mathrm{~nm}$ at $100 \mathrm{~ms} / \mathrm{scan}$ with a resolution of $6.5 \mathrm{~nm}$ and selectively monitoring the absorbance at $595 \mathrm{~nm}$; the fluorescence detector excitation was $365 \mathrm{~nm}$ and emission was monitored at $607 \mathrm{~nm}$. The Surveyor system PDA was scanned from 250 to $750 \mathrm{~nm}$ at $100 \mathrm{~ms} / \mathrm{scan}$ with a resolution of $5 \mathrm{~nm}$. The elution gradient started with 50:50 A:B [A, water $10 \mathrm{mM}$ ammonium acetate $(\mathrm{pH} 6.0) ; \mathrm{B}$, methanol $10 \mathrm{mM}$ ammonium acetate] at a flow rate of $200 \mu \mathrm{L} / \mathrm{min}$, holding 5 min, ramping to $5: 95 \mathrm{~A}: \mathrm{B}$ at $20 \mathrm{~min}$, holding $20 \mathrm{~min}$, and returning to $50: 50 \mathrm{~A}: \mathrm{B}$ at $45 \mathrm{~min}$, with an equilibration time of $15 \mathrm{~min}$. Injection volumes were $20 \mu \mathrm{L}$ of extracts diluted to 50:50 water:methanol.

Positive and negative electrospray ionization mass spectrometry was performed with a Deca-XP-plus ion trap (ITMS, Thermo Scientific, Waltham, MA), with the ITMS placed inline and operated in either positive or negative electrospray ionization modes (ESI+, ESI-). Additional MS(n), collisioninduced dissociation (CID), and ion-mapping experiments were performed with introduction by HPLC and by infusion. Accurate mass analyses were performed by infusion-only using a linear ion-trap-orbitrap hybrid instrument (Orbitrap XL, Thermo Scientific, Waltham, MA). The tentative structure of the component(s) was elucidated by the accurate mass measurements and heuristic rules using the seven-rules script ${ }^{11}$ for EXCEL (Microsoft, Redmond, WA), and fragment ions from HRMS $(\mathrm{n})$ experiments were interpreted using MetFrag. ${ }^{12}$

Stentor coeruleus Culture and Preparation. A source of highly pigmented $S$. coeruleus was obtained (ScienceKit and Boreal Laboratories, VWR-Education LLC, Pittsburgh, PA) and cultured. ${ }^{13}$ Approximately $500 \mathrm{mg}$ (wet weight) of cultured $S$. coeruleus were collected by centrifugation and filtration. Stentorin was extracted and partially purified as described for isolation of the colored/fluorescent component from the 2006female EL catfish and the 2009-ovary containing eggs.

Medaka Bioaccumulation. A biological research model using medaka (Orizias latipes) was used to conduct a feeding study based on the identified dietary source of the pigment. The transparent transgenic medaka strain, olvas gpf, were a kind gift from Dr. Yuko Wakamatsu. ${ }^{14}$ This species is not indigenous to EL but rather was chosen for its transparency, allowing simple in vivo examination for $S$. coeruleus by both the distinctive blue-green coloration and an orange-red fluorescence of the ingested stentors. Four individual $2 \mathrm{yr}$ old gravid medaka, approximately $3 \mathrm{~cm}$ and $600-650 \mathrm{mg}$, were 

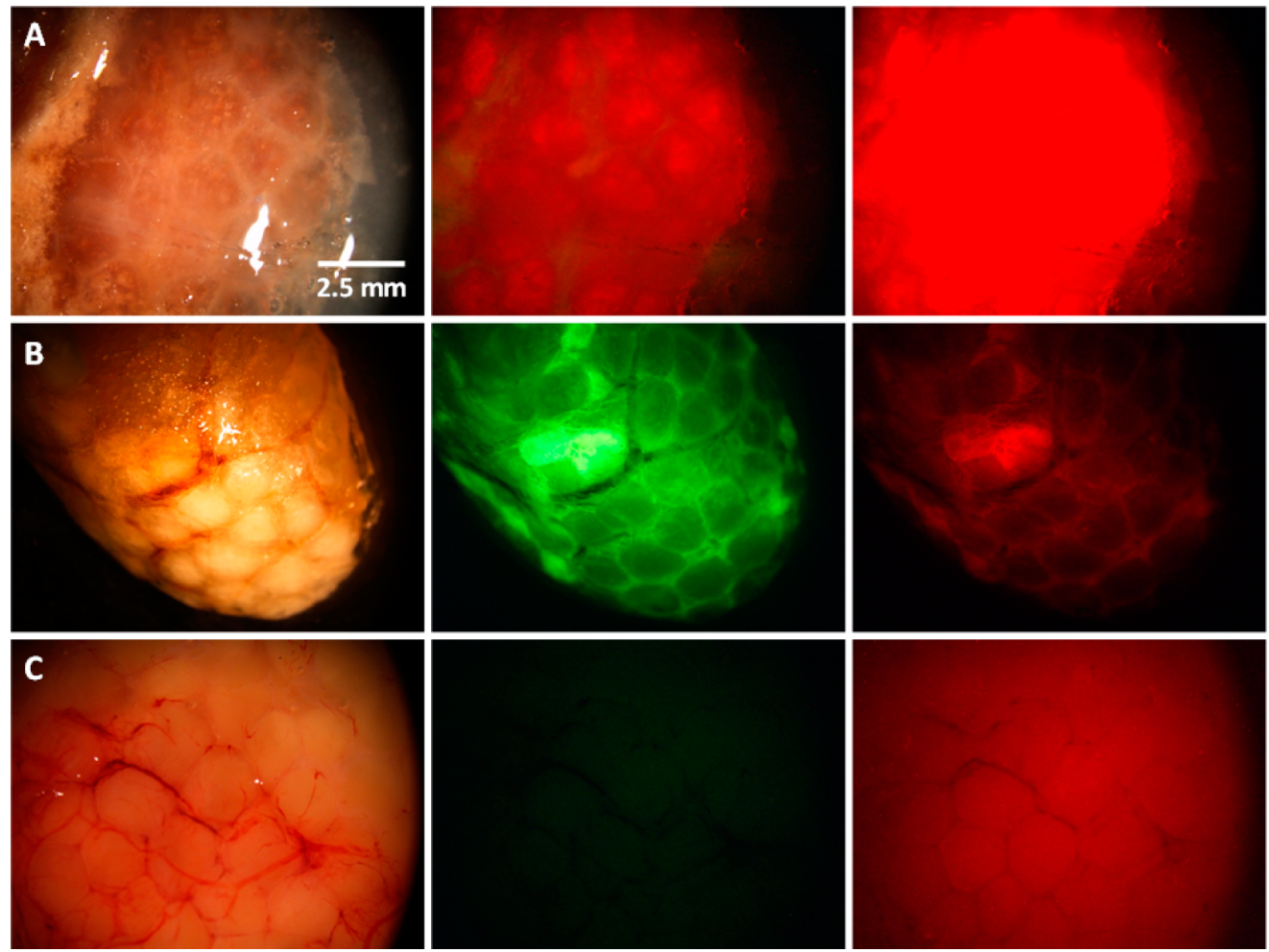

Figure 2. Epifluorescence microscopy of catfish ovaries. Top to bottom: (A) discolored ("purple") ovaries from Eufaula Lake 2006, (B) normal ovaries from Eufaula Lake 2009, and (C) normal ovaries from Missouri River 2011. Left to right: dark field illumination with white light, fluorescence from blue excitation, fluorescence from green excitation. Scale bar applies to all images. Acquisition times $100 \mathrm{~ms}$ for all images, except MR-green excitation, which was $15 \mathrm{~s}$.

maintained in $2 \mathrm{~L}$ glass aquaria supplied with well water at ambient temperature (ca. $21^{\circ} \mathrm{C}$ ) and aeration. Fish were fed $S$. coeruleus or standard Tetramin diets ad libitum for 2 weeks. Complete water changes were performed manually twice weekly. A subsequent feeding study utilized 2-3 d old medaka maintained in Petri dishes. Four larval fish (6.5-7.0 mm, 4-5 $\mathrm{mg}$ ) were fed an ad libitum diet of paramecia and colpidia augmented with about $10 \%$ (by number) live S. coeruleus for 23 days prior to examination.

\section{RESULTS}

Visual and Microscopic Examination. Fresh, discolored ovaries appeared more red than purple under ambient (white fluorescent) lighting. Flash photography also enhanced the red color. Once frozen, the discolored ovaries appeared more blue than purple or red. This was first observed when the frozen tissues were cut under white light. They turned gray-green upon thawing and the gray-green color remained stable and occurred even when the frozen ovaries were cut under nitrogen or in $0.1 \mathrm{~N}$ citric acid. Under long-wavelength UV light, the discolored ovaries with eggs, fluids from affected fish, and to a lesser extent other tissues, exhibited an intense orange-red fluorescence with less intense fluorescence under shortwavelength UV light. Fresh and frozen normal-appearing ovaries with eggs from EL and MR catfish were light yellowcream color with no visibly observable fluorescence under longor short-wavelength UV light. Fresh and frozen spent ovaries from normal EL catfish were also reddish under white light, but no bluish or gray-green color was evident after freezing or thawing, and frozen and thawed tissues did not visibly fluoresce under long or short-wavelength UV light.
Microscopic examination under dark field illumination with white light revealed that normal ovary tissues from EL and the MR catfish appeared yellow-white, whereas the discolored ovary tissues from EL were reddish-brown under dark field illumination with white light (Figure 2). Under blue excitation (100 ms acquisition time), the discolored EL ovaries strongly fluoresced red with traces of green fluorescence. Normal EL ovaries strongly fluoresced green under blue excitation, with brighter green regions delineating the interstitial regions between eggs. There was no visible red fluorescence; however, green excitation (to avoid the strong green fluorescence) produced a weaker red fluorescence. Normal MR catfish ovaries only weakly fluoresced green with blue excitation, and there was no red fluorescence with green excitation. The discolored EL ovaries most strongly fluoresced red under green excitation; any residual green fluorescence would not have been excited and would have been removed by the emission filter. Normal EL ovaries exhibited moderate red fluorescence under green excitation, with brighter red fluorescence again in the interstitial regions. No fluorescence was evident under green excitation in normal MR ovaries after $100 \mathrm{~ms}$ of acquisition, but weak red fluorescence became visible after $15 \mathrm{~s}$ (150-fold longer than all other acquisition times) (Figure 2). No fluorescence was evident under blue or green excitation of the spent ovaries from normal EL catfish.

No red fluorescence was evident in formalin-preserved tissues or histological sections prepared from discolored or normal ovarian tissues from EL or MR collected in 2006-2007 when observed under epifluorescence. Moreover, histopathological analysis of gonads of EL females indicated no differences between normal and discolored ovaries (Table S3). 


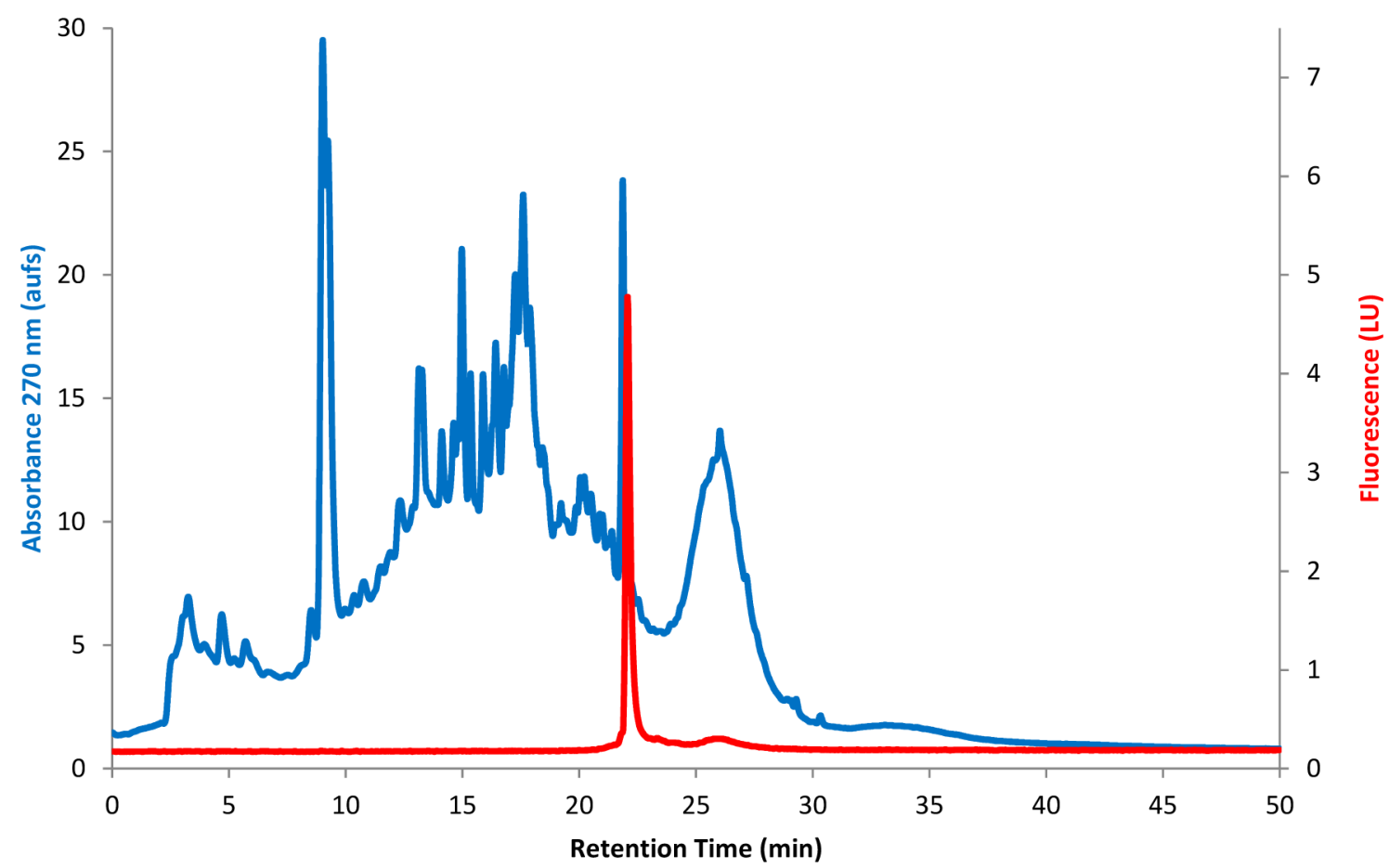

Figure 3. HPLC-UV (blue) and F (red) chromatograms of the extract of Eufaula Lake female catfish discolored ("purple") ovary from 2006. Only one fluorescent component was detected. UV absorbance, $270 \mathrm{~nm}$; fluorescence excitation, $366 \mathrm{~nm}$; and emission, $607 \mathrm{~nm}$.

Chemical Characterization. The observed orange-red fluorescence in tissues of affected fish (Figure S2) was most evident in the ovaries with eggs and was used to direct chemical extraction and fractionation. The gray-green, orange-red fluorescent tissues or fluids produced a clear gray-green solution with orange-red fluorescence (similar in color to the thawed ovary sample) and a light gray-brown (nonfluorescent) precipitate after homogenization and acetone extraction. There was no evidence of the original reddish-purple or blue colors visible in the fresh or frozen samples, respectively. A clear, dark red (and red fluorescent) waxy ring was left on the tube wall just above the aqueous layer and a nonfluorescent pale-yellow precipitate formed after the wet acetone extract was centrifuged and the acetone supernatant evaporated under nitrogen. The red waxy material was soluble in hexane, forming a deep red solution with intense orange-red fluorescence (Figure S3). The red color and fluorescence was partitioned from the hexane layer by addition of methanol, producing a gray-green, orangered fluorescent solution in the methanol. There was no observed loss of color or fluorescence.

Methanolic solutions of acetone extracts of normal ovaries with eggs were clear and almost colorless, and exhibited yellowgreen fluorescence under long-wavelength UV light; extracts from spent ovary were also clear and nearly colorless but exhibited light blue fluorescence (Figure S4). Although these components were characterized spectrophotometrically and spectrofluorometrically, no further efforts were made to identify or quantify the fluorophors.

The ultraviolet-visible absorption spectra and fluorescence excitation and emission spectra of the partially purified extracts in methanol were acquired. The gray-green extracts displayed intense UV absorption $(200-350 \mathrm{~nm})$ and significant absorption in the visible range (Figure S5). The long wavelength absorption bands were distinct at $595 \mathrm{~nm}(100)$, 552 (75, shoulder), 532 (50), 512 (23), 478 (35), and 445 (45) $\mathrm{nm}$ (relative intensity). Acidification to $\mathrm{pH} 2$ induced hypsochromic shifts at 582 (100), 566 (60), 540 (60), 498 (40), and $460(75) \mathrm{nm}$; basification to $\mathrm{pH} 10$ induced a decrease in long-wavelength absorption and induced bathochromic shifts at $608(100)$ and $562(60) \mathrm{nm}$.

Although the extracts fluoresced over a wide range of excitation wavelengths, two emission maxima were evident (Figure S5). The first was a short-wavelength $(354-510 \mathrm{~nm}$ ) peak that decreased in intensity with decreasing excitation energies (longer wavelengths). The second, which was responsible for the visible orange-red fluorescence characteristic of the discolored ovaries, was a narrow, longer-wavelength (600-602 nm) peak that did not appreciably shift with changes in the excitation wavelength and reached maximum emission intensity at an excitation wavelength of $342 \mathrm{~nm}$.

Molecular size range was investigated using a cut-off filter, which provided equivocal results due to strong binding of the fluorescent pigment(s) to the filter (Figure S6). In addition to the lipophilicity observed in solvent partitioning, the fluorescent material was extractable with the protein fraction during preparation for PAGE. This material bound weakly to the major protein bands during electrophoresis, perhaps through nonspecific interactions with lipoproteins such as vitellogenins (Figure S7).

The unique absorption and fluorescence characteristics of the partially purified orange-red fluorescent extract were used to establish HPLC methods to identify the potential fluorescent components. A methanol-water reverse-phase gradient system with $10 \mathrm{mM}$ ammonium acetate buffer ( $\mathrm{pH}$ 6.0) using a $\mathrm{C}_{8}$ column was effective. Conversely, elution from $\mathrm{C}_{8}$ using methanol, acetone, acetonitrile, dichloromethane, or ethyl acetate, (without ammonium acetate) was not effective. This indicated that ion-pairing interactions were necessary for elution of the component(s). 
A complex mixture of compounds with significant UV absorbance eluted throughout the chromatogram (Figure 3, UV trace). The mixture was detectable at $365 \mathrm{~nm}$ but was most intense at $270 \mathrm{~nm}$. The HPLC-fluorescence separations identified a single component fluorescing at $607 \mathrm{~nm}$ (Figure 3 , fluorescence trace). This peak corresponded to a UV-V absorption peak at $595 \mathrm{~nm}$ within a narrow retention-time window that was targeted for mass spectrometry. No other components fluorescing near $600 \mathrm{~nm}(550-650 \mathrm{~nm})$ or with a $\mathrm{UV}-\mathrm{V}$ absorption maximum near $595 \mathrm{~nm}(550-650 \mathrm{~nm})$ were detected.

During the isolation procedure, the fractions resulting from each cleanup step were screened by positive and negative electrospray ionization mass spectrometry. Sample introduction of the fractions by both infusion and by HPLC were used with low-resolution full-scan MS and precursor/product ion scan MS(n) experiments. Initial screening without elution information about the fluorescent and UV-V absorbing component was unsuccessful. Retrospective examination of these results revealed the presence of the component of interest, but at a low response $\left(\sim 10^{-4}\right)$ relative to residual matrix components.

Tentative identification of the fluorescent, UV-V absorbing component in the partially purified fractions by MS was performed with an ITMS placed inline and operated in either positive or negative electrospray ionization modes (ESI+, ESI-). A single component that correlated with the PDA peak response at $595 \mathrm{~nm}$ was observed only in the ESI- mode (Figure S8). The pseudomolecular ion of the fluorescent component was determined to be $m / z 591$ (neutral mass 592 $\mathrm{Da})$. Using this low-mass resolution value, $>152000$ possible CHNOPS-only molecular formulas were generated. ${ }^{15}$ The fragmentation profile of the fluorescent component was elaborated using additional MS(n), collision-induced dissociation (CID), and ion-mapping experiments with introduction by both HPLC and infusion. The MS $(n=1-5)$ fragmentation results (Figure S9) indicated only losses of $-\mathrm{CH}_{3},-\mathrm{CH}_{4}$ and $-\mathrm{H},-\mathrm{CO},-\mathrm{C}_{3} \mathrm{H}_{7}$, and $-\mathrm{CH}_{2} \mathrm{CO}$.

Accurate mass and pseudomolecular isotope cluster information were acquired to unambiguously identify the molecular formula, fragmentation, and observed losses. Accurate mass analyses were performed by infusion using a linear ion-trap-orbitrap hybrid instrument operating at a resolution of 120000 at $\mathrm{m} / z 591$. The accurate mass of the pseudomolecular ion, $[\mathrm{M}-\mathrm{H}]^{-}$was $591.1302 \pm 0.00083 \mathrm{Da}$ (3 SD, or about $1.3 \mathrm{ppm}$ ) averaged over several analyses. The isotopic cluster ratios $\left([\mathrm{M}-\mathrm{H}]^{-},[\mathrm{M}+1-\mathrm{H}]^{-},[\mathrm{M}+2-\mathrm{H}]\right.$ -, and $\left.[\mathrm{M}+3-\mathrm{H}]^{-}\right)$were $100 \%, 33.3 \%, 2.89 \%$, and $0.01 \%$, respectively. Accurate mass measurements confirmed the losses from MS $(n=1-3)$ analyses for $-\mathrm{CH}_{3},-\mathrm{CH}_{4}$ and $-\mathrm{H},-\mathrm{CO}$, $-\mathrm{C}_{3} \mathrm{H}_{7}$, and $-\mathrm{CH}_{2} \mathrm{CO}$, which is consistent with highly hydroxylated phenanthroperylene quinones [e.g., hypericin ${ }^{16}$ (1,3,4,6,8,13-hexahydroxy-10,11-dimethylphenanthro[1,10,9,8$0, p, q, r, a]$ perylene-7,14-dione) $]$. The tentative structure of the unknown fluorescent molecule was elucidated by the accurate mass measurements and heuristic rules and was substantiated by literature reports of absorption, fluorescence, and mass spectra. ${ }^{17-24}$ Collectively, the UV-V and fluorescence excitation and emission spectra, accurate mass measurements, and mass spectral fragmentation information were consistent with stentorin $\left(\mathrm{C}_{34} \mathrm{H}_{24} \mathrm{O}_{10}\right.$; monoisotopic MW 592.13696 Da; Chemical Abstracts Registry Number 147395-58-2; Figure 4), the fluorescent, phenanthroperylene quinone pigment uniquely associated with the photoreceptor protein of $S$. coeruleus

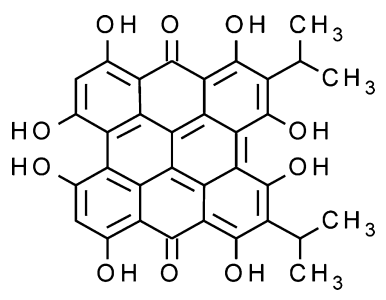

Figure 4. Stentorin (1,3,4,6,8,10,11,13-octahydroxy-2,5-diisopropylphenanthro[1,10,9,8,o,p,q,r,a]perylene-7,14-dione) $\mathrm{C}_{34} \mathrm{H}_{24} \mathrm{O}_{10}$. The blue-green colored and orange-red fluorescent pigment associated with the photoreceptor protein of the blue-green protozoan ciliate $S$. coeruleus.

(Figure S10) [Concurrence by H. Falk, 2012, personal communication].

Confirmation of Stentorin. Three methods were considered for confirming stentorin as the component tentatively identified [H. Falk 2012, personal communication]: (1) comparison with an authentic stentorin standard material; however, there are no available sources of stentorin; (2) chemical synthesis of the anthrone followed by dimerization and chromatographic separation from other regioisomers, ${ }^{18}$ which is very labor intensive; and (3) culturing $S$. coeruleus and isolating stentorin. We extracted and partially purified stentorin from the cultured $S$. coeruleus as described for isolation of the fluorescent component from the 2006-female EL catfish. Characterization of authentic stentorin by $\mathrm{UV}-\mathrm{V}$ absorption spectra, fluorescence excitation and emission spectra, and HPLC-PDA-MS and ITMS(n) was consistent with the tentative identification of stentorin as the pigment we extracted from the 2006-female catfish from Eufaula Lake (Figures S9 and S11).

S. coeruleus Consumption by Medaka. Ovigerous female medaka consumed $S$. coeruleus in the laboratory; however, a $100 \%$ S. coeruleus diet resulted in greatly decreased feeding rates (relative to standard Tetramin diet) and initiated egg reabsorption, indicating that the diet of $100 \%$ S. coeruleus is nutritionally insufficient, toxic, or both to adult medaka. Related phenanthroperylene quinones are ingestion deterrents capable of causing photohemolysis. ${ }^{19}$ Larval medaka fed a diet of paramecia and colpidia augmented with live $S$. coeruleus ingested stentors without noticeable [short-term] adverse effects, and the blue-green stentors were visible in the gastrointestinal tract of the fish under dark field illumination with white light (Figure 5). With the use of epifluorescence microscopy, fluorescence similar to that observed in the catfish ovaries was observed in the medaka.

\section{DISCUSSION}

Chemistry of Stentorin and Toxicology of Related Compounds. Stentorin biogenesis by $S$. coeruleus occurs via two consecutive cascades: an acetate malonate pathway cyclization into an emodin anthroquinone, followed by oxidative dimerization to two emodin molecules. ${ }^{19}$ The compound is bound to the photoreceptor protein in pigment granules at the base of the cilia; it is not fluorescent when bound. The protein, which is also called stentorin, has two forms: stentorin I (ethanol extractable and fluorescent) and stentorin II (nonethanol extractable and nonfluorescent). The protein photoreceptor serves to control movement of the ciliate with respect to light intensity in the water column. ${ }^{13,18,19,22-24}$ Stentorin is released upon protein denaturation or stress to the 

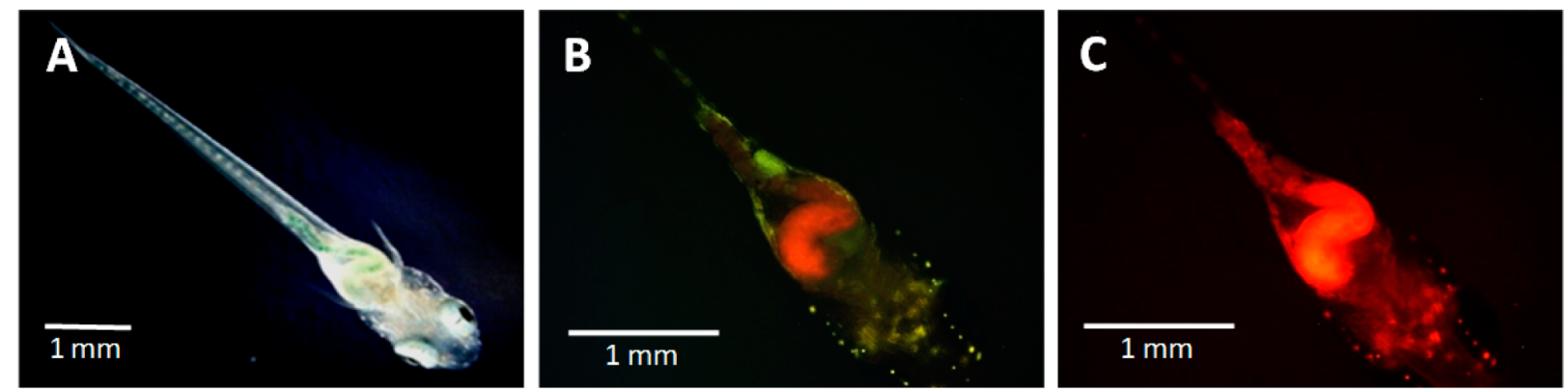

Figure 5. Epifluorescence microscopy images of larval medaka fed S. coeruleus. (A) Dark field illumination with white light, (B) blue excitation, and (C) green excitation.

stentor. The unbound pigment exhibits intense orange-red fluorescence (Figure S10), which we observed in the gastrointestinal tract of the larval medaka (Figure 5).

Stentorin is lipophilic (pred. $\left.\log K_{\mathrm{ow}}=9.5\right)^{25}$ and is likely to bioaccumulate, but its binding properties and transport have not been well-studied. Hypericin, a structurally similar compound, is the most thoroughly investigated phenanthroperylene quinone (Table S4). It binds to lipoproteins, can be transported throughout tissues in animals, and forms complexes with DNA, human serum albumin, and low and high density lipoproteins. Hypericin uptake and clearance from normal tissue is rapid and occurs without significant degradation, but the compound accumulates in small tumors. Because of this property and its singlet oxygen/superoxide radical formation capability, it is used in photodynamic therapies. ${ }^{19,26-28}$ Hypericin also causes varying degrees of enzymatic inhibition and has been used as a drug-sparing agent. Other phenanthroperylene quinones in plants (e.g., St. John's wort, Hypericum perforatum; buckwheat, Fagopyrum sp.), crinoids (sea lilies and other crinoid species), and in other heterotrich ciliates are ingestion deterrents. Consumption of Hypericum sp. and Fagopyrin sp. by grazing animals can cause photohemolysis (Table S4). Stentorin has also been shown to deter predation on $S$. coeruleus by the ciliate Dileptus margertifera, to which the compound is also toxic. ${ }^{29}$ The absorbance shift of stentorin in hexane we observed indicates that the original purple color was a result of the pigment being preferentially bound to hydrophobic regions within the ova, but the effects of stentorin accumulation on fish and other vertebrates are unknown. For additional information about phenanthroperylene quinone chemistry, see reviews by Falk ${ }^{19}$ and Lobban. ${ }^{39}$

Biology of S. coeruleus. S. coeruleus is one of 21 known species of heterotrich stentorids. It is a turquoise to blue-green unicellular ciliate that, in contrast to many other stentorids, contains no symbiotic algae. It is comparatively large (up to 2 $\mathrm{mm}$ long; $10^{6}$ individuals weigh about $12000 \mathrm{mg}$ ), ${ }^{30}$ and it is common in eutrophic Midwestern U.S. waters. ${ }^{31} \mathrm{~S}$. coeruleus tolerates flowing or stagnant waters of $0-10 \%$ salinity and $0-$ $5000 \mathrm{mg} / \mathrm{L}$ chloride (oligo-euryhaline) and typically inhabits the recovery zone of polluted waterways ( $\alpha$ - to $\beta$-mesosaprobity). ${ }^{30,32} S$. coeruleus may be epibenthic, periphytic, or planktonic; it also undergoes vertical migrations in response to dissolved oxygen and ambient light ${ }^{33,34}$ and feeds primarily on autotrophic organisms, protozoans, and metazoans. Stentorids (including S. coeruleus) form large-scale blooms when conditions are favorable ${ }^{35-39}$ [C. Lobban 2012 personal communication].

There are few published reports of direct predation on stentors. The cylopoid copepod Mesocyclops araucanus fed on $S$. araucanus and S. amethystinus in North Patagonia lakes, ${ }^{40,41}$ but calanoid copepods (Acanthodioptomus sp.) avoided S. coeruleus. $^{42}$ S. amethystinus and S. araucanus (but not S. coeruleus) were probably not important in the diets of juvenile fish of both native and introduced species in North Patagonia lakes; speciesspecific consumption rates were estimated as at most $0.2 \%$ of fish biomass (3-53 stentors/fish/day). ${ }^{40,41}$ In contrast, ciliates comprised up to $60 \%$ of the carbon intake of larval fish in some Estonia lakes. ${ }^{43}$ Direct predation on $S$. coeruleus by zooplankton (Acanthodiaptomus denticornis and Cyclops vicinus) has been reported, ${ }^{44}$ but predation by wild fish has not.

Bioaccumulation of Stentorin in Eufaula Lake. Stentorin is unique to $S$. coeruleus; consequently, we suspect that the stentors, their detritum, or other food web prey that previously consumed stentors or detritum is the initial step in stentorin bioaccumulation by fish (see the Supporting Information for an expanded discussion). Among reported zooplankton surveys, ${ }^{45,46}$ we could find no reports of the presence, abundance, or distribution of $S$. coeruleus in EL. On the basis of relative fluorescence intensities of extracts of stentorin from $S$. coeruleus and from the catfish, and percent lipid values in whole catfish and ovaries, we estimate that about $10^{4}-10^{5}$ individual stentors (about $0.1-1.0 \mathrm{~g}$ ) would have had to be consumed by a typical young female catfish (with eggs) to produce the concentrations seen in the EL catfish (Table S5). Unknowns, including $S$. coeruleus pigmentation, fish size and lipid and lipoprotein content, and metabolism, depuration, and timing relative to egg development, make better estimations impracticable.

S. coeruleus flourishes in waters receiving organic pollution. Hence, we suspect that conditions favorable for increasing blooms of S. coeruleus ${ }^{13,30,35,37}$ were present following the 2000 WWTP release and subsequent (2005-2006) industrial effluent releases into the Deep Fork and North Canadian rivers, which feed the highly eutrophic northern arm of EL. Discolored egg occurrence peaked in 2006-2007, six years after the earlier pollution event but only one year after the second pollution event. The occurrence of discolored eggs decreased in subsequent years, and there have been no recent reports. The observation of the pollution events followed by the discoloration of catfish ovaries is consistent with a stentor bloom in response to an episodic organic pollution event. Stentorin is a highly lipophilic biogenic compound that appears, by fluorescence imaging, to accumulate in fish eggs and other lipid-rich tissues (Figure 2 and Figure S2). Our limited analyses of normal EL and MR fish indicate that stentorin accumulation may be common in fish, but that high concentrations resulting in discolored ovaries with eggs may only occur when hydrologic and ecological conditions are favorable for S. coeruleus blooms. 
The frequency, magnitude, extent, and potential toxicological significance of such blooms and of stentorin bioaccumulation in fish and higher trophic level organisms (including wildlife and humans) are unknown.

\section{ASSOCIATED CONTENT}

\section{S Supporting Information}

The Supporting Information is available free of charge on the ACS Publications website at DOI: 10.1021/acs.est.5b02273.

Discussion about the potential route of bioaccumulation of stentorin, Tables S1-S5, and Figures S1-S11 (PDF)

\section{AUTHOR INFORMATION}

\section{Corresponding Author}

*Phone: +1-573-441-2971; fax: +1-573-876-1896; e-mail: rgale@usgs.gov.

\section{Author Contributions}

The manuscript was written through contributions of all authors. All authors have given approval to the final version of the manuscript.

Notes

The authors declare no competing financial interest.

\section{ACKNOWLEDGMENTS}

This research was jointly supported by USGS (Environmental Health Mission Area) and the U.S. Army Corps of Engineers (Tulsa, Oklahoma District; COE). Collaboration with T. Clyde (COE) and S. Woods and R. Miller (Connor State University) was especially beneficial. The U.S. Fish and Wildlife Service Columbia Fisheries Resource Office collected MR blue catfish. D. Nicks, J. Candrl, M. Tanner, V. Velez, M. Wright-Osment, W. Marler, T. Dunn, S. Buck, C. Orazio, and D. Tillitt (all USGS) participated in the study, and N. Leigh [University of Missouri (UM) CORE Facility], S. Pucciarelli (University of Camerino), W. Foissner (Universitat Salzburg), N. Kamjunke (Helmholtz Center for Research), and C. Lobban (University of Guam) provided valuable insight. D. True (UM Resource Assessment Partnership) prepared the map. Special thanks to R. Chong (Biosecurity Queensland) for discussions about food web versus disease processes and to $\mathrm{H}$. Falk (Johannes Kepler University) for commenting on our experimental information and discussions about stentorin synthesis and biochemistry, and to E. Furlong and L. Iwanowicz (USGS) and three anonymous reviewers for comments on an earlier version of this manuscript. Use of trade, product, or firm names is for descriptive purposes only and does not imply endorsement by the U.S. Government.

\section{REFERENCES}

(1) Bowen, D. Eufaula Lake 5-Year Management Plan; Oklahoma Department of Wildlife Conservation: Oklahoma City, OK, 2008; p 38.

(2) Stephenson, J. B. Hazardous Waste: Environmental Protection Agency's Cleanup of the Eagle-Picher Henryetta, Oklahoma, Site; GAO03-1051R; U.S. General Accounting Office: Washington, D.C., 2003.

(3) Schmitt, C. J.; Whyte, J. J.; Roberts, A. P.; Annis, M. L.; May, T. W.; Tillitt, D. E. Biomarkers of metals exposure in fish from lead-zinc mining areas of southeastern Missouri. Ecotoxicol. Environ. Saf. 2007, 67, 31-47.

(4) Cp Kelco USA, Inc., Okmulgee, Oklahoma. http://projects. nytimes.com/toxic-waters/polluters/facility/1024 (accessed Sep 15, 2014).
(5) Oklahoma Department of Environmental Quality: Spill/Unusual Discharge/Fish Kill Program. http://www.deq.state.ok.us/WQDnew/ 305b_303d/2000_305b/2000_305b_Appendices.pdf (accessed Sep $15,2014)$.

(6) Nutrition and Fish Health; Webster, C. D., Lim, C., Eds.; Taylor and Francis: Binghamton, NY, 2001; p 396.

(7) Frank, R. H., Jr. Trace Metal Pollution of the Lower North Canadian River Basin; Univeristy of Oklahoma: Oklahoma City, 1969; p 160.

(8) Water Quality Technical Report: Eufaula Lake, Oklahoma; United States Army Corps of Engineers Tulsa District: Tulsa, Oklahoma, 2012; pp 1-159.

(9) Roosevelt, M. The Tragedy of Tar Creek. Time 2004, 1-5.

(10) Schmitt, C. J. Biomonitoring of Environmental Status and Trends (BEST) Program: Environmental contaminants and Their Effects on Fish in the Mississippi River Basin; Biological Science Report USGS/BRD/BSR-2002-0004; U.S. Geological Survey, Reston, VA; 2002; pp 1-260.

(11) Kind, T.; Fiehn, O. Seven Golden Rules for heuristic filtering of molecular formulas obtained by accurate mass spectrometry. BMC Bioinf. 2007, 8, 105.

(12) Wolf, S.; Schmidt, S.; Müller-Hannemann, M.; Neumann, S. In silico fragmentation for computer assisted identification of metabolite mass spectra. BMC Bioinf. 2010, 11, 148.

(13) Tartar, V. The Biology of Stentor. In International Monographs on Pure and Applied Biology; Kerkut, G. A., Ed.; Pergammon Press: London, 1961; Vol. 5, p 413.

(14) Wakamatsu, Y.; Pristyazhnyuk, S.; Kinoshita, M.; Tanaka, M.; Ozato, K. The see-through medaka: a fish model that is transparent throughout life. Proc. Natl. Acad. Sci. U. S. A. 2001, 98, 10046-10050.

(15) Patiny, L.; Borel, A. ChemCalc: a building block for tomorrow's chemical infrastructure. J. Chem. Inf. Model. 2013, 53, 1223-1228.

(16) Hecka, A.; Maunit, B.; Aubriet, F.; Muller, J.-F. Study of active naphtodianthrone St John's Wort compounds by electrospray ionization Fourier transform ion cyclotron resonance and multi-stage mass spectrometry in sustained off-resonance irradiation collisioninduced dissociation and infrared multiphoton dissociation modes. Rapid Commun. Mass Spectrom. 2009, 23, 885-898.

(17) Cameron, D. W.; Riches, A. G. Synthesis of Stentorin. Aust. J. Chem. 1997, 50, 409-424.

(18) Dai, R.; Yamazaki, T.; Yamazaki, I.; Song, P.-S. Initial spectroscopic characterization of the ciliate photoreceptor stentorin. Biochim. Biophys. Acta, Bioenerg. 1995, 1231, 58-68.

(19) Falk, H. From the Photosensitizer Hypericin to the Photoreceptor Stentorin- The Chemistry of Phenanthroperylene Quinones. Angew. Chem., Int. Ed. 1999, 38, 3116-3136.

(20) Falk, H.; Mayr, E. Syntheses, Constitutions and Properties of Stentorin and lsostentorin. Monatsh. Chem. 1995, 126, 1311-1321.

(21) Falk, H.; Schoppel, G. On the synthesis of hypericin by oxidative trimethylemodin anthrone and emodin anthrone dimerization: isohypericin. Monatsh. Chem. 1992, 123, 931-938.

(22) Höfle, G.; Reinecke, S.; Laude, U.; Spitzner, D. Amethystin, the coloring principle of Stentor amethystinus. J. Nat. Prod. 2014, 77, $1383-1389$.

(23) Iio, H.; Zenfuku, K.; Tokoroyama, T. A facile synthesis of stentorin, the photoreceptor of Stentor coeruleus. Tetrahedron Lett. 1995, 36, 5921-5924.

(24) Mukherjee, P.; Fulton, D. B.; Halder, M.; Han, X.; Armstrong, D. W.; Petrich, J. W.; Lobban, C. S. Maristentorin, a novel pigment from the positively phototactic marine ciliate Maristentor dinoferus, is structurally related to hypericin and stentorin. J. Phys. Chem. B 2006, 110, 6359-6364.

(25) $\log \mathrm{P}$ and $\log \mathrm{D}$ for Stentorin: Predicted data is generated using the ACD/Labs' Percepta Platform - PhysChem Module. http://www. chemspider.com/Chemical-Structure.9257672.html (accessed Jul 24, 2015).

(26) Chung, P. S.; Saxton, R. E.; Paiva, M. B.; Rhee, C. K.; Soudant, J.; Mathey, a; Foote, C.; Castro, D. J. Hypericin uptake in rabbits and nude mice transplanted with human squamous cell carcinomas: study 
of a new sensitizer for laser phototherapy. Laryngoscope 1994, 104, $1471-1476$.

(27) Crnolatac, I.; Huygens, A.; Agostinis, P.; Kamuhabwa, A. R.; Maes, J.; van Aerschot, A.; De Witte, P. a M. In vitro accumulation and permeation of hypericin and lipophilic analogues in 2-D and 3-D cellular systems. Int. J. Oncol. 2007, 30, 319-324.

(28) Karioti, A.; Bilia, A. R. Hypericins as potential leads for new therapeutics. Int. J. Mol. Sci. 2010, 11, 562-594.

(29) Miyake, A.; Harumoto, T.; Iio, H. Defence function of pigment granules in Stentor coeruleus. Eur. J. Protistol. 2001, 37, 77-88.

(30) Foissner, W.; Berger, H. A user-friendly guide to the ciliates (Protozoa, Ciliophora) commonly used by hydrobiologists as bioindicators in rivers, lakes, and waste waters, with notes on their ecology. Freshwater Biol. 1996, 35, 375-482.

(31) Eddy, S. A study of fresh-water plankton communities; Illinois Biological Monographs; Univeristy of Illinois, Urbana Press: Urbana, Illinois, 1934; Vol. XII, p 112.

(32) Dias, R. J.; Wieloch, A. H.; D'Agosto, M. The influence of environmental characteristics on the distribution of ciliates (Protozoa, Ciliophora) in an urban stream of southeast Brazil. Braz. J. Biol. 2008, 68, 287-295.

(33) Sprugel, G. Vertical distribution of Stentor coeruleus in relation to dissolved oxygen levels in an Iowa pond. Ecology 1951, 32, 147149.

(34) Cadotte, M. W.; Jantz, S.; Mai, D. V. Photo-dependent population dynamics of Stentor coeruleus and its consumption of Colpidium striatum. Can. J. Zool. 2007, 85, 674-677.

(35) Bai, A. R. K.; Murthy, K. V. N. Seasonal Blooms of a Red Stentor. Trans. Am. Microsc. Soc. 1975, 94, 425-427.

(36) Elber, F.; Schanz, F. The causes of change in the diversity and stability of phytoplankton communities in small lakes. Freshwater Biol. 1989, 21, 237-251.

(37) Pucciarelli, S.; Buonanno, F.; Pellegrini, G.; Pozzi, S.; Ballarini, P.; Miceli, C. Biomonitoring of Lake Garda: Identification of ciliate species and symbiotic algae responsible for the "black-spot" bloom during the summer of 2004. Environ. Res. 2008, 107, 194-200.

(38) Lobban, C. S.; Schefter, M. Blooms of a benthic ciliate, Maristentor dinoferus (Heterotrichida: Maristentoridae), on coral reefs of Guam, Mariana Islands. Micronesica 2012, 43, 114-127.

(39) Lobban, C. S.; Hallam, S. J.; Mukherjee, P.; Petrich, J. W. Invited Review - Photophysics and Multifunctionality of Hypericin-Like Pigments in Heterotrich Ciliates: A Phylogenetic Perspective. Photochem. Photobiol. 2007, 83, 1074-1094.

(40) Kamjunke, N.; Kramps, M.; Chavez, S.; Woelfl, S. Consumption of large, Chlorella-bearing ciliates (Stentor) by Mesocyclops araucanus in North Patagonian lakes. J. Plankton Res. 2012, 34, 922-927.

(41) Kamjunke, N.; Vogt, B.; Woelfl, S. Trophic interactions of the pelagic ciliate Stentor spp. in North Patagonian lakes. Limnologica 2009, 39, 107-114.

(42) Hartmann, H. J.; Taleb, H.; Aleya, L.; Lair, N. Predation on Ciliates by the Suspension Feeding Calanoid Copepod Acanthodiaptomus Denticornis. Can. J. Fish. Aquat. Sci. 1993, 50, 1382-1393.

(43) Zingel, P.; Paaver, T.; Karus, K.; Agasild, H.; Nõges, T. Ciliates as the crucial food source of larval fish in a shallow eutrophic lake. Limnol. Oceanogr. 2012, 57, 1049-1056.

(44) Lair, N. Effects of invertebrate predation on the seasonal succession of a zooplankton community: a two year study in Lake Aydat. Hydrobiologia 1990, 198, 1-12.

(45) Bowles, L. G.; Wilhm, F. Effects of patchiness on estimates of concentration and species. Southwestern Association of Naturalists 1977, 21, 463-468.

(46) Canfield, T. J.; Jones, J. R. Zooplankton abundance, biomass, and size-distribution in selected midwestern waterbodies and relation with trophic state. J. Freshwater Ecol. 1996, 11, 171-179. 


\section{Supporting Information}

\section{Bioaccumulation of Stentorin, the Probable}

\section{Causative Agent for Discolored ("Purple") Eggs and}

\section{Ovaries in Blue Catfish (Ictalurus furcatus) from}

\section{Eufaula Lake, Oklahoma, USA}

Robert W. Gale*, Diana M. Papoulias, and Christopher J. Schmitt.

U.S. Geological Survey, Columbia Environmental Research Center, Columbia, MO, USA.

*Robert W. Gale. Phone: +1-573-441-2971. Fax:+1-573-876-1896. E-mail: rgale@usgs.gov.

Number of pages: 27

Number of figures: 11

Number of Tables: 5

This supporting information contains: 11 Figures listed below that give more information about the site, the distribution of fluorescent pigments in blue catfish and the isolation of the main pigment responsible for the 'purple' eggs; 5 Tables listed below that summarize metals and 
organohalogenated contaminants screening of the blue catfish, histology, related phenanthroperylene quinones in plants and animals, and the calculations used for estimating the stentor-equivalents consumed by the EL catfish; and an extended discussion about the potential mode of bioaccumulation of the pigment.

\section{Table of Contents of Supporting Information:}

This supporting information contains the following:

Figure S1. Eufaula Lake, Oklahoma.

Figure S2. Epifluorescence microscopy of tissues.

Figure S3. Qualitative extraction of 2006 Eufaula Lake male and female blue catfish.

Figure S4. Visible appearance and fluorescence of extracts of female catfish from Eufaula Lake..

Figure S5. UV-Visible absorption spectrum and fluorescence emission spectra of extracts of Lake Eufaula 2006-Female catfish 'purple' ovary.

Figure S6. White light and fluorescence of MW filtration of extracts of Eufaula Lake 2006female blue catfish 'purple' ovary.

Figure S7. non-SDS-DTT PAGE of protein extracts of the Eufaula Lake female catfish discolored ("purple") ovary from 2006 and the normal ovary from 2009.

Figure S8. Comparison of LC-UV and LC-MS chromatograms and PDA and ESI(-) spectra of the fluorescent component extracted from the Eufaula Lake female catfish 2006 and stentorin extracted from Stentor coeruleus. 
Figure S9. Composite mass spectrum of MS(5) experiment for the fluorescent component extracted from the Eufaula Lake female catfish 2006.

Figure S10. Laboratory-reared S. coeruleus and denaturation of photoreceptor proteins resulting in orange-red fluorescent pigment.

Figure S11. Infusion ESI(-) MS/MS spectra for the fluorescent component extracted from the Eufaula Lake female catfish 2006 and stentorin extracted from Stentor coeruleus.

Table S1. Concentrations ( $\mu \mathrm{g} / \mathrm{g}$ dry wt) of total recoverable elements in whole fish from Eufaula Lake, Oklahoma, determined by ICP-MS semi-quantitative scan.

Table S2. Concentrations (ng/g wet wt) of polychlorinated biphenyls, polybrominated diphenylethers, and persistent organochlorine pesticides in whole fish from Eufaula Lake.

Table S3. Blue Catfish (BC) histology samples from Eufaula Lake, and the Missouri River.

Table S4. Related phenanthroperylene quinones identified in plants and animals.

Table S5. Estimation of S. coeruleus consumed by Eufaula Lake catfish.

Extended Discussion: Bioaccumulation of stentorin in Eufaula Lake. 


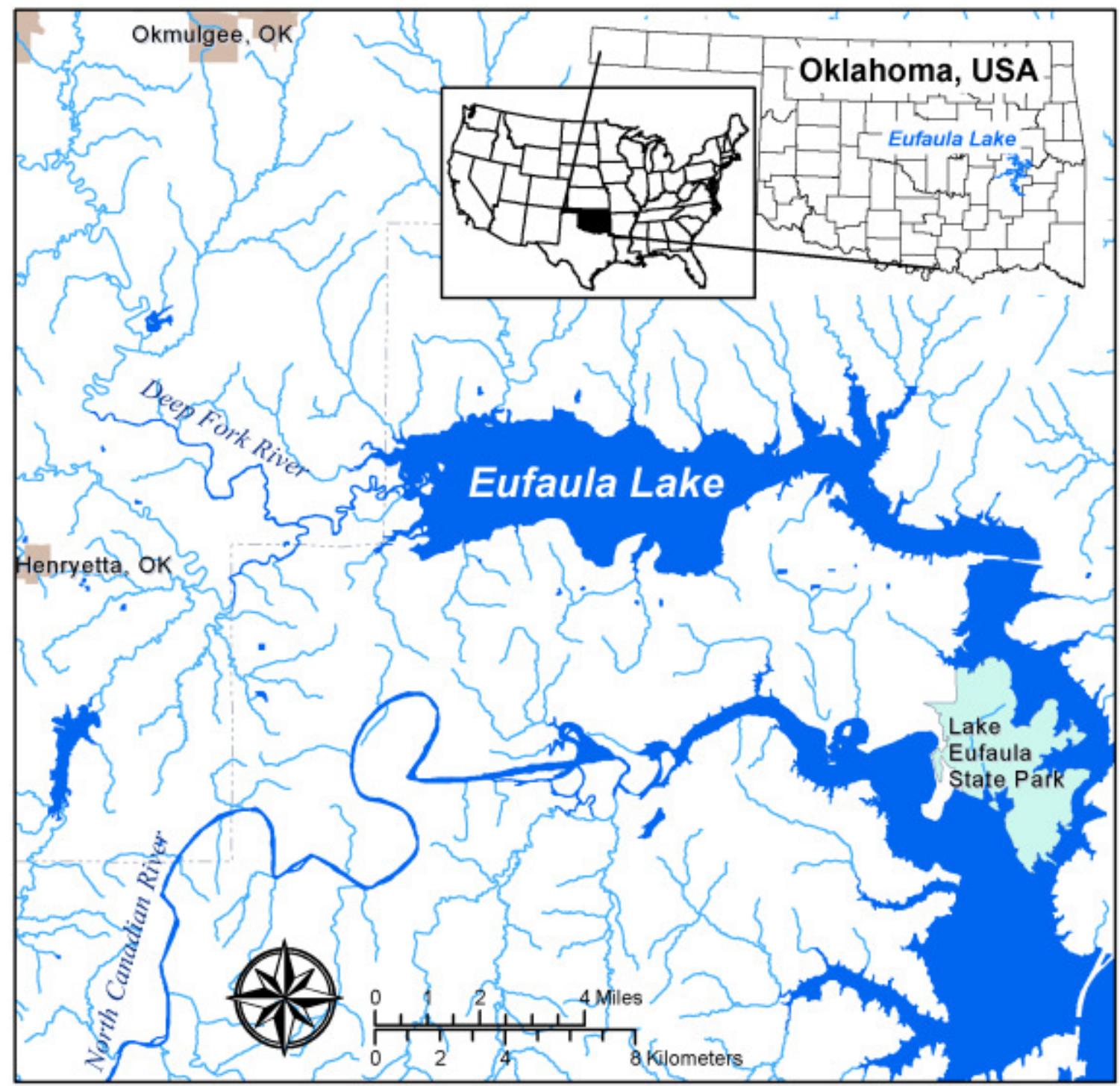

Figure S1. Eufaula Lake, Oklahoma. Most reports of discolored ovaries (an estimated 25\% of the female fish) were from the northern arm of the lake (Deep Fork and North Canadian Rivers) above Lake Eufaula State Park. 


\section{Epifluorescence of Tissues}

Epifluorescence microscopy of tissues (other than ovaries/eggs) of the Eufaula Lake blue catfish indicated that both the yellow-green and the orange-red fluorescent pigments were widely distributed.

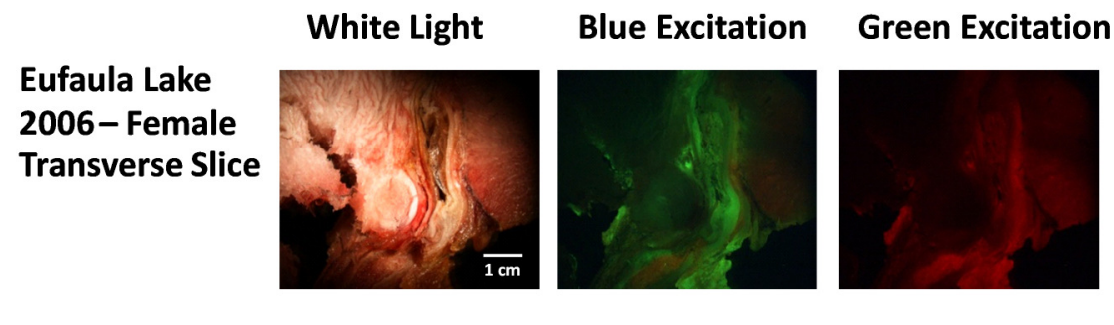

Liver

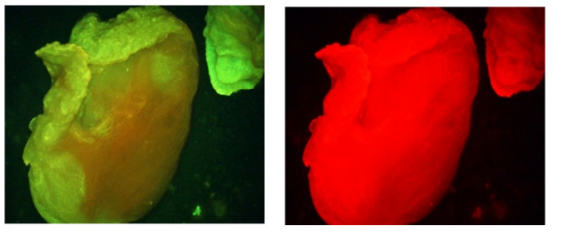

Blood Vessel
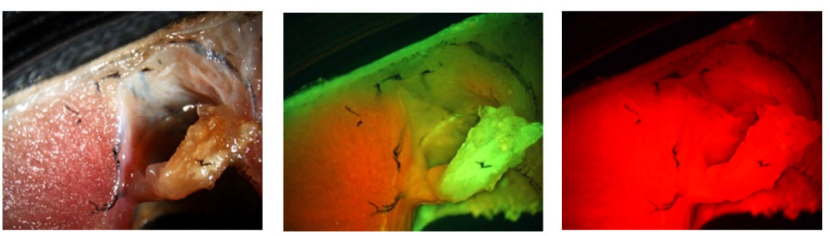

Mesentery
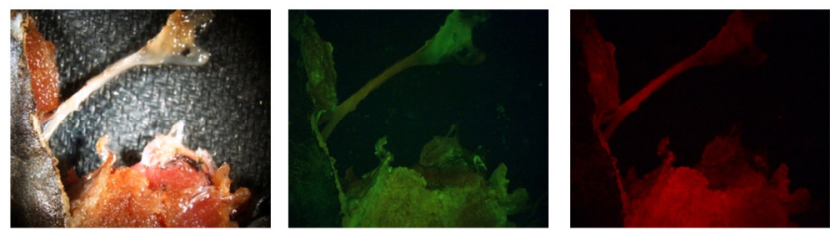

\section{Eufaula Lake 2006-Male Skin/Muscle}
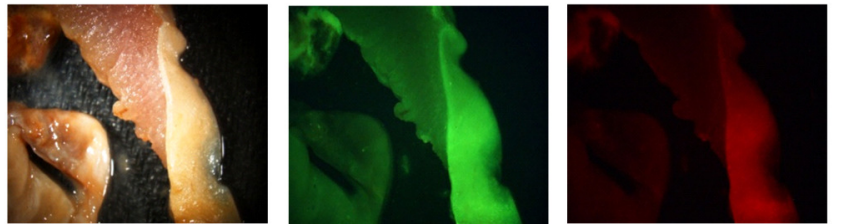

Figure S2. Epifluorescence microscopy of tissues from the 2006-female (with discolored ovaries) and a 2006-male from a nearby location. Scale applies to all images. 


\section{Qualitative Extracts of Eufaula Lake Male and Female Blue Catfish from 2006}

The extraction of male and female tissue from 2006 Eufaula Lake blue catfish showed that no orange-red fluorescent component was present in the male; however, a blue fluorescence component was observed. This component may be present in the extract from the female, but obscured by the overwhelming orange-red fluorescence. We note that the orange-red fluorescent component appears green in polar solvents (acetone and methanol) and rose red in non-polar solvent (hexane). Fluorescence was only slightly affected by solvent - most of the difference seen in the figure is the result of positioning differences relative to the excitation source.

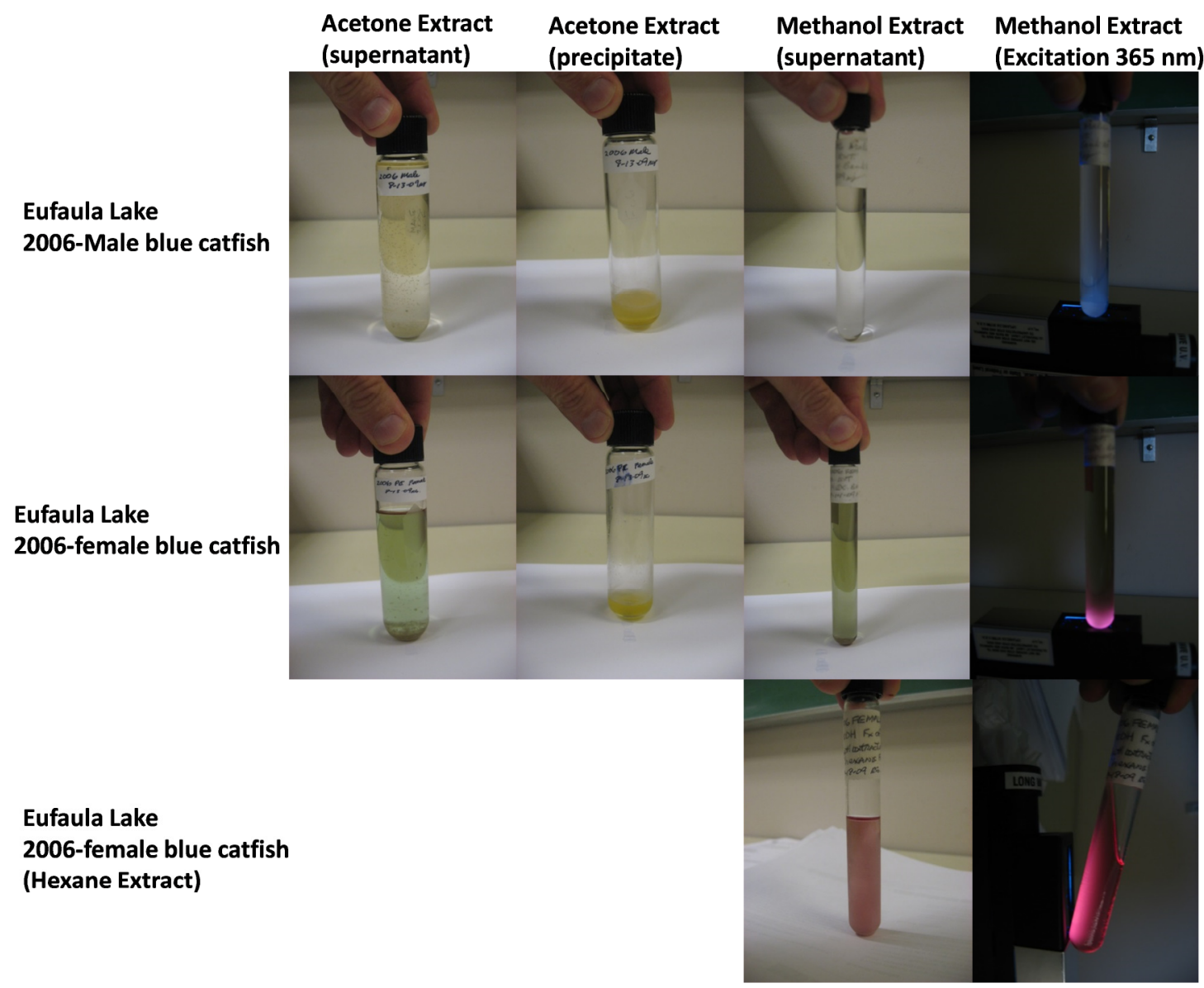

Figure S3. Qualitative extraction of 2006 Eufaula Lake male and female blue catfish. 

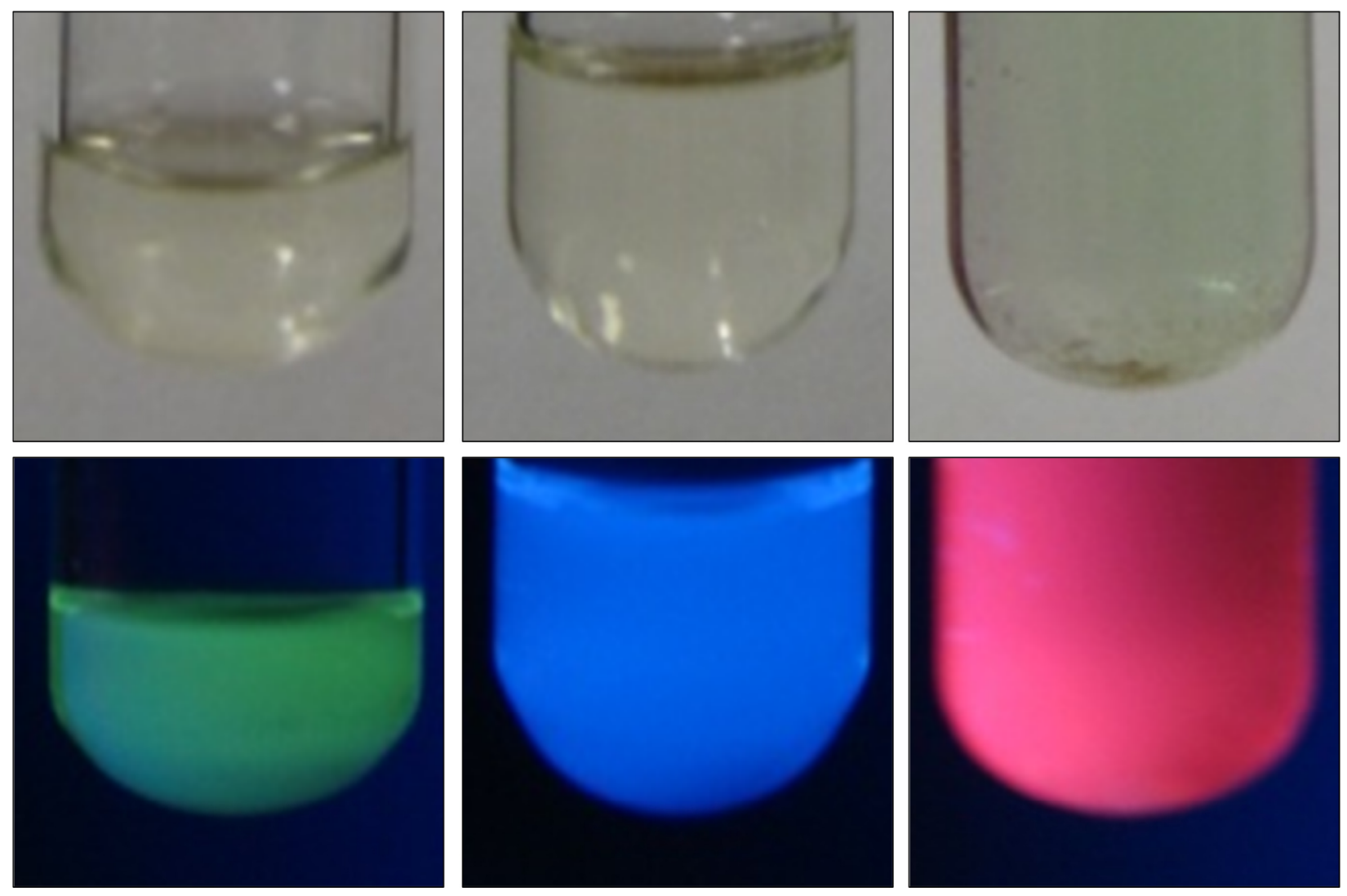

Figure S4. Visible appearance (upper) and fluorescence of extracts (lower) of female catfish from Eufaula Lake: normal ovary from 2009 (left) spent ovary from 2009 (center), and discolored ("purple") ovary from 2006 (right). Fluorescence excitation $365 \mathrm{~nm}$. 

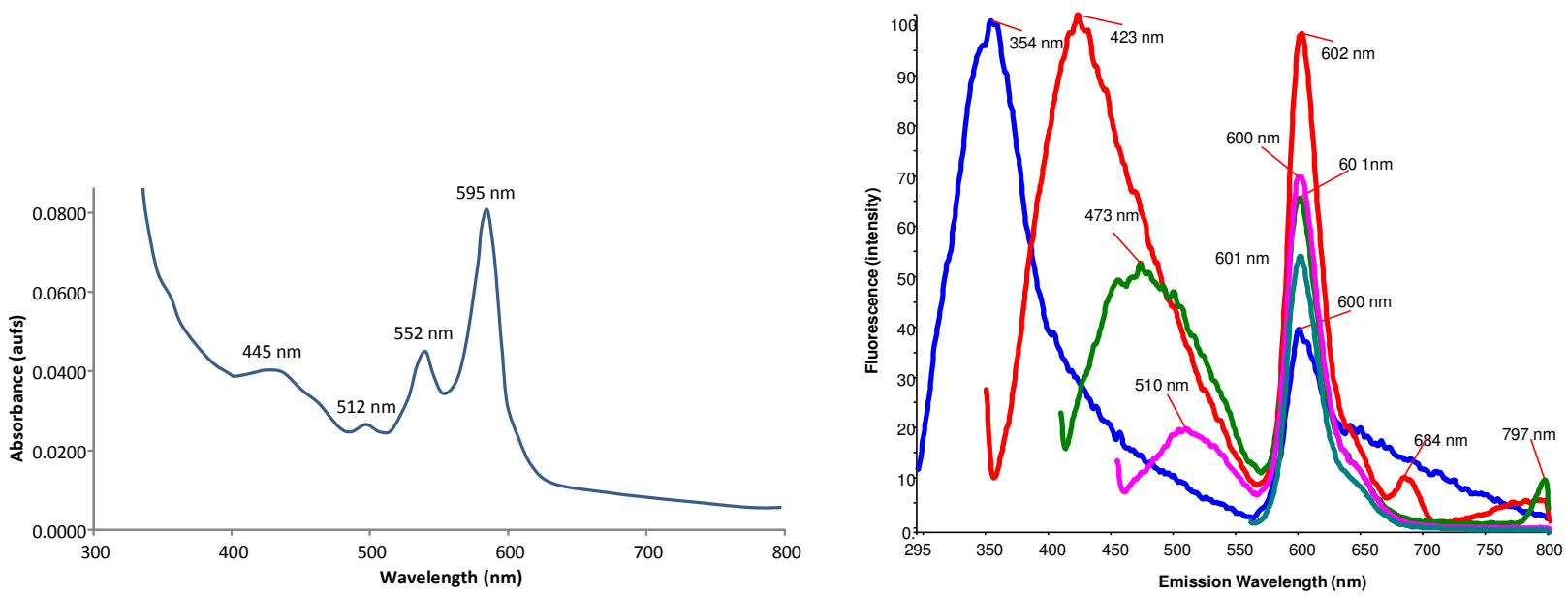

Figure S5. UV-Visible absorption spectrum (A) and fluorescence emission spectra (B) of extracts of Lake Eufaula 2006-Female catfish 'purple' ovary. Fluorescence excitation $285 \mathrm{~nm}$ (blue), $342 \mathrm{~nm}$ (red), $399 \mathrm{~nm}$ (green), $446 \mathrm{~nm}$ (magenta), and $551 \mathrm{~nm}$ (dark green). Emission peaks are denoted. 


\section{Molecular Size Range Estimation}

To estimate the approximate molecular weight, a portion of the cleaned-up orange-red fluorescent extract (in methanol) was filtered through a Millipore Ultrafree-MC 5kDa centrifugal unit (EMD Millipore, Billerica, MA). Some of the orange-red fluorescent material irreversibly bound to the polyethersulfone filter and was only recoverable by dissolution of the filter in dichloromethane. The rest of the orange-red fluorescent material passed through the filter.

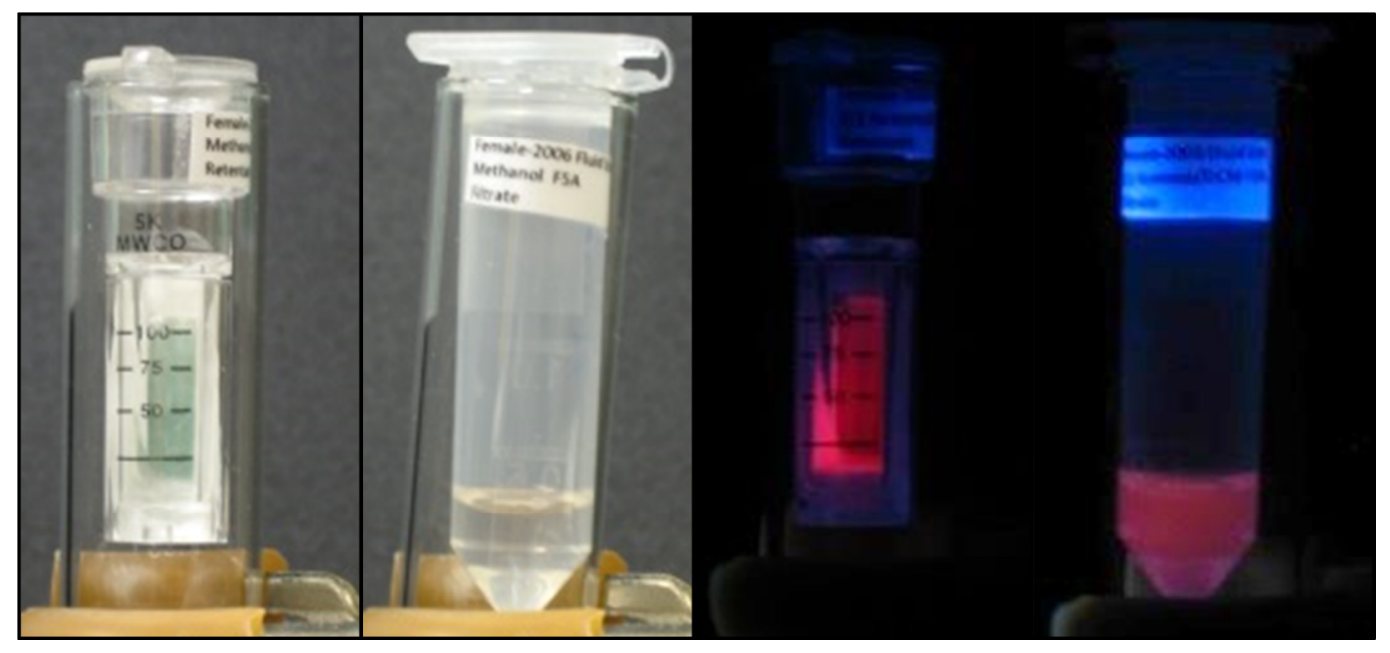

Figure S6. White light (left) and fluorescence (right) images of MW filtration (5 kDa cutoff) of extracts of Eufaula Lake 2006-female blue catfish 'purple' ovary. Fluorescence excitation 365 nm.

Size-exclusion chromatographic separation of a portion of the extract using SX-3 bio beads (BioRad, Laboratories, Hercules, CA) with a dichloromethane mobile phase resulted in the orangered fluorescent component eluting in the higher molecular weight (>500 Da) fraction. This fraction is known to occur through a combination of size-exclusion and $\pi$ - $\pi$ * interaction mechanisms, however. 
Polyacrylamide Gel Electrophoretic (PAGE) Separation of Proteins Associated with Fluorescent Components

Protein binding of the orange-red fluorescent material was explored by polyacrylamide gel electrophoresis (PAGE). 1x CelLytic B protein extractions (in 0.1 M ZPS pH 6.5) of the 2006 EL discolored ovary and from normal 2009 EL ovary were separated by non-SDS-DTT native discontinuous PAGE (Bio-Rad Ready Gel 12\%, 12 well, 2x native sample loading buffer, 25mM tris and $192 \mathrm{mM}$ glycine running buffer $\mathrm{pH}$ 8.3). The fluorescent material was only weakly bound to the protein bands, perhaps through non-specific interactions with lipoproteins such as vitellogenins. Normal EL catfish ovaries with eggs were found to contain the pigment, but at much lower concentrations.

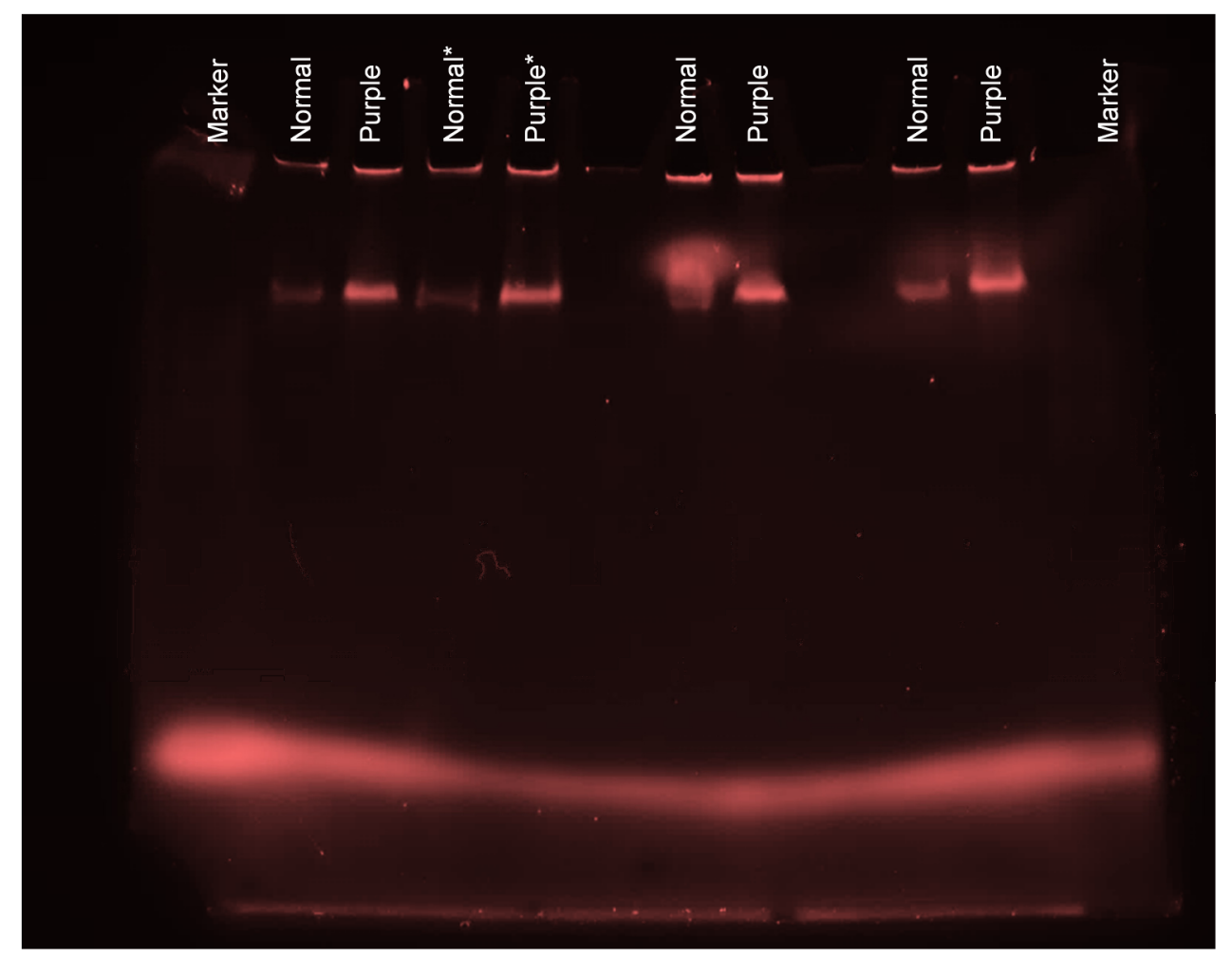

Figure S7. non-SDS-DTT PAGE of protein extracts of the Eufaula Lake female catfish discolored ("purple") ovary from 2006 and the normal ovary from 2009. 
LC-PDA-ESI(-)MS Comparisons of the Fluorescent Component with Stentorin (Extracted from Stentor coeruleus).
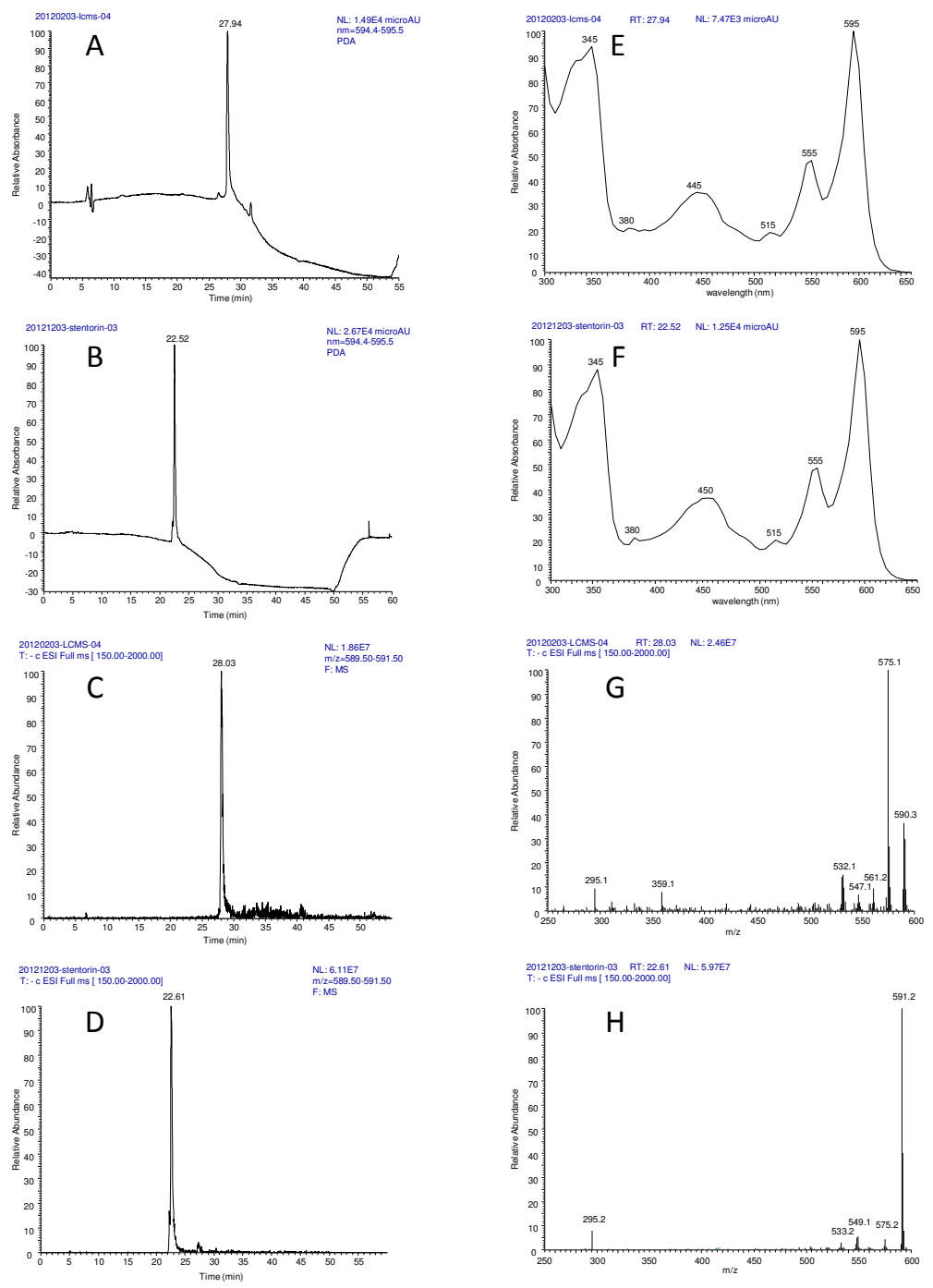

Figure S8. Comparison of LC-UV and LC-MS chromatograms and PDA and ESI(-) spectra of the fluorescent component extracted from the Eufaula Lake female catfish 2006 and stentorin extracted from Stentor coeruleus. LC-PDA $(595 \mathrm{~nm})$ chromatograms of Lake Eufaula extract (A) and stentorin (B); LC-MS (m/z 589.5-591.5) chromatograms of Lake Eufaula extract (C) and stentorin (D); UV-Vis spectra (300-650 nm) of Lake Eufaula extract (E) and stentorin (F); ESI(-) mass spectra (m/z 250-600) of Lake Eufaula extract (G) and stentorin $(\mathrm{H})$. 
ESI(-) MS(n) Experiments Investigating the Fragmentation of the Fluorescent Component. The MS(n) fragmentation results indicated only losses of $-\mathrm{CH}_{3},-\mathrm{CH}_{4}$ and $-\mathrm{H},-\mathrm{CO},-\mathrm{C}_{3} \mathrm{H}_{7}$, and $-\mathrm{CH}_{2} \mathrm{CO}$, which is consistent with highly hydroxylated phenanthroperylene quinones, e.g., hypericin.

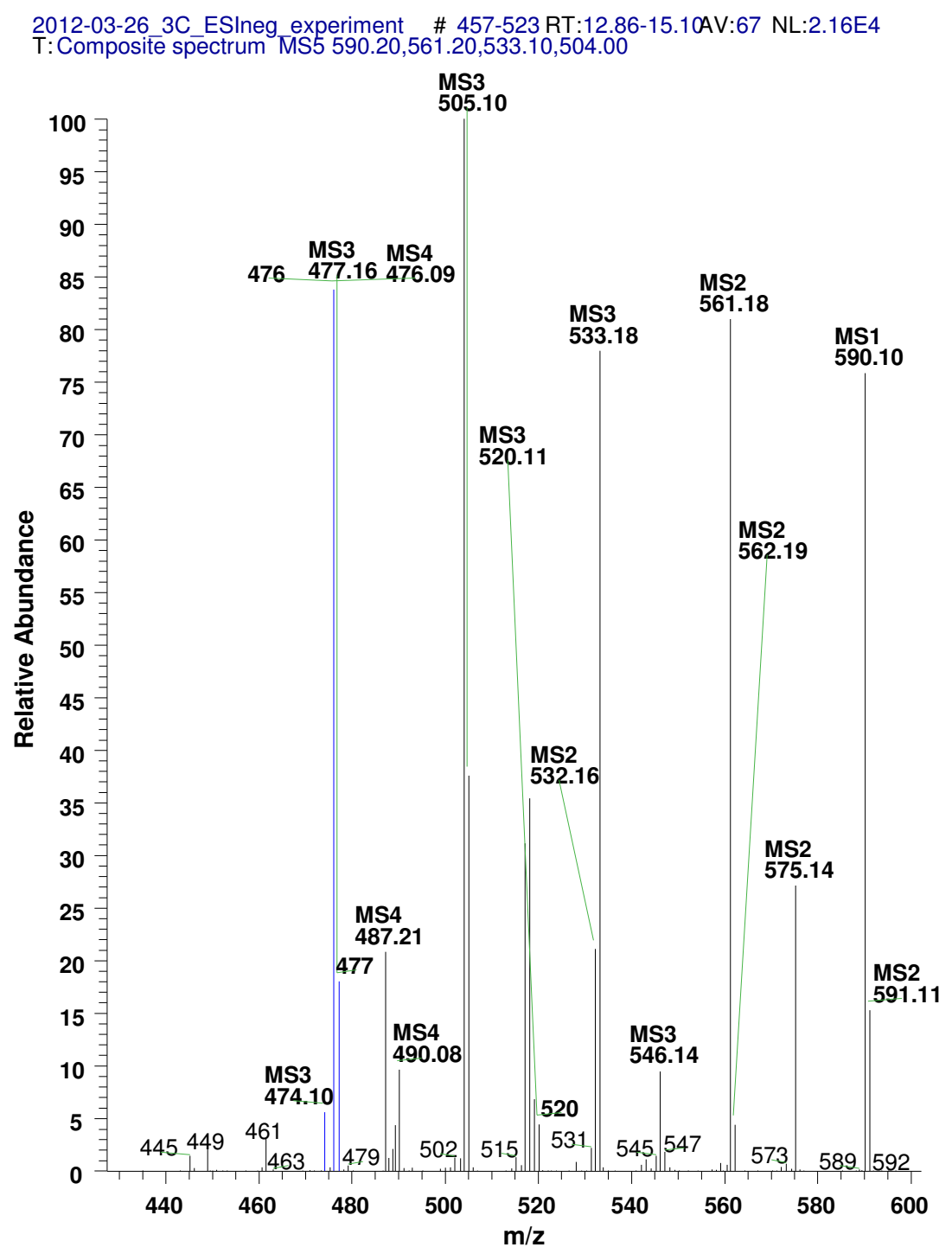

Figure S9. Composite mass spectrum of MS(5) experiment for the fluorescent component extracted from the Eufaula Lake female catfish 2006. Precursor ions: MS2 m/z 590.2, MS3 $\mathrm{m} / \mathrm{z} 561.2$, MS4 m/z 533.1, MS5 m/z 504.0. 

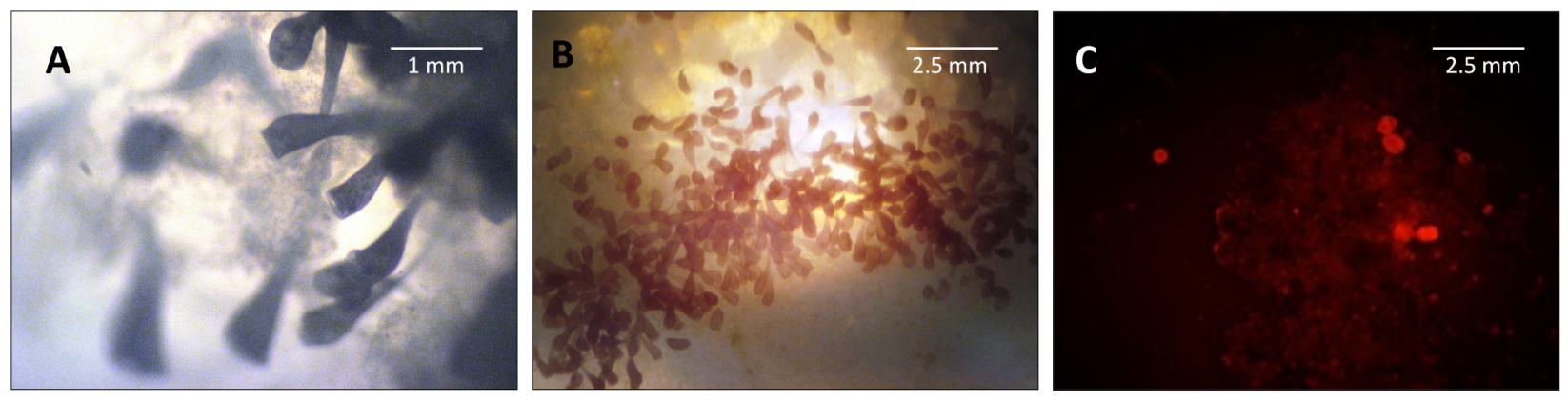

Figure S10. Laboratory-reared S. coeruleus. S. coeruleus is about $0.5-2 \mathrm{~mm}$ long and $0.1-0.2$ $\mathrm{mm}$ in diameter (left, center). Exposure to stress (here ethanol) causes denaturation of photoreceptor proteins (stentorin I and II) and release of the orange-red fluorescent pigment (stentorin; right). Also shown (right) is the weaker fluorescence of the naturally released (burst) pigment granules, the sloughing of the granules themselves, and shedding of some layers of the pellicle (outermost secretory membranes of the cell). 
ESI(-)MS/MS Comparison of the Fluorescent Component with Stentorin (Extracted from

Stentor coeruleus).

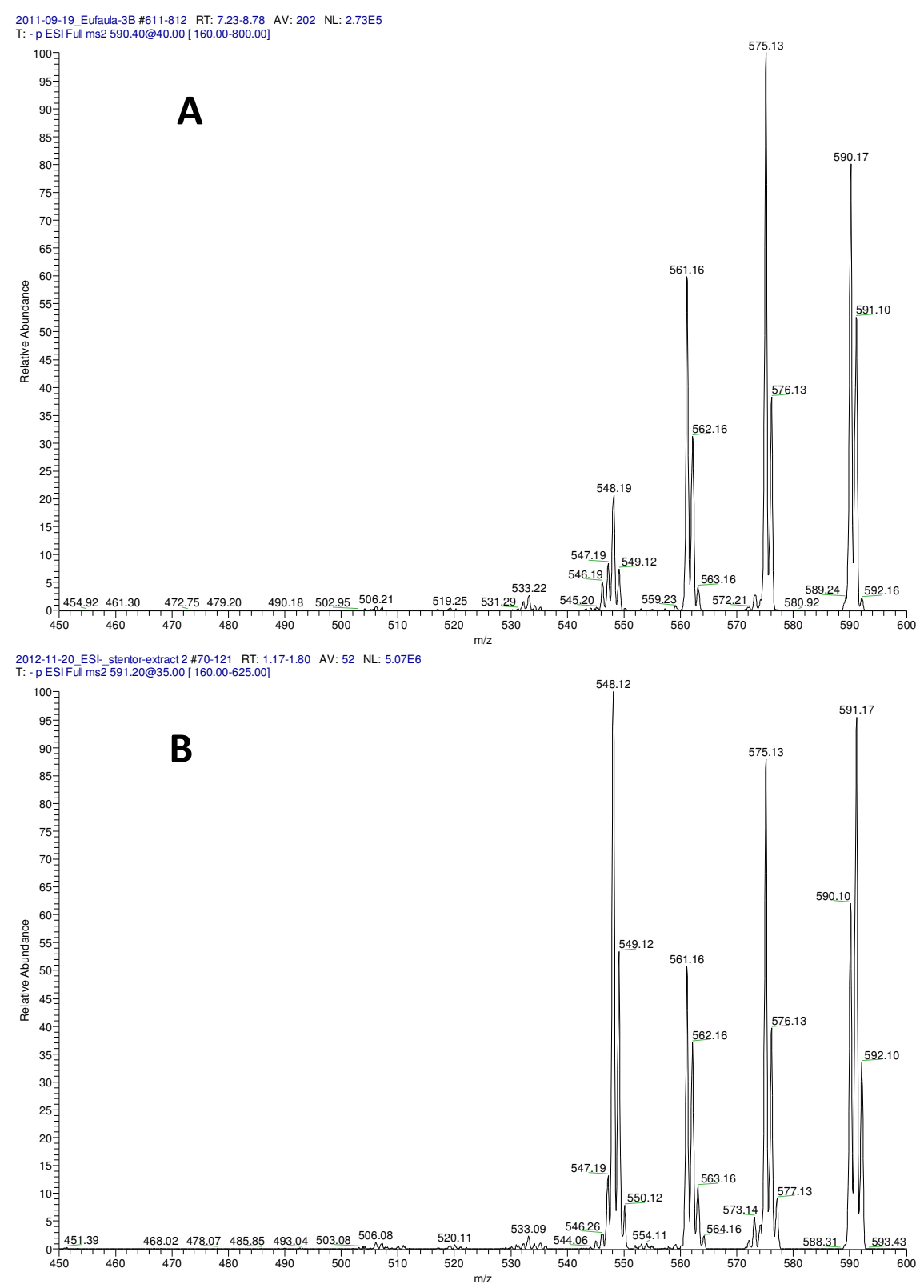

Figure S11. Infusion ESI(-) MS/MS spectra for the fluorescent component extracted from the Eufaula Lake female catfish 2006 and stentorin extracted from Stentor coeruleus. (A) Lake Eufaula extract Precursor ion m/z 590.4; (B) stentorin Precursor ion 591.2. 
Table S1. Concentrations ( $\mu \mathrm{g} / \mathrm{g}$ dry wt) of total recoverable elements in whole fish from Eufaula Lake, Oklahoma, determined by ICP-MS semi-quantitative scan.

50861

Fish Ovary

Element

Normal 2009

\begin{tabular}{|c|c|}
\hline Ag & $<0.02$ \\
\hline Al & $<420$ \\
\hline As & 0.3 \\
\hline $\mathrm{Au}$ & $<0.02$ \\
\hline $\mathbf{B a}$ & 1.0 \\
\hline Be & $<0.02$ \\
\hline $\mathbf{B i}$ & 0.06 \\
\hline $\mathbf{B r}$ & 320 \\
\hline $\mathbf{C a}$ & 1500 \\
\hline Cd & $<0.02$ \\
\hline $\mathrm{Ce}$ & $<0.02$ \\
\hline Co & 0.05 \\
\hline $\mathrm{Cr}$ & 2.0 \\
\hline Cs & $<0.02$ \\
\hline $\mathbf{C u}$ & 4.00 \\
\hline Dy & $<0.02$ \\
\hline $\mathbf{E r}$ & $<0.02$ \\
\hline $\mathbf{E u}$ & $<0.02$ \\
\hline $\mathbf{F e}$ & $<2$ \\
\hline $\mathbf{G a}$ & $<2$ \\
\hline Gd & $<0.02$ \\
\hline Ge & $<0.02$ \\
\hline Hf & $<0.02$ \\
\hline Ho & $<0.02$ \\
\hline In & $<0.02$ \\
\hline Ir & $<0.02$ \\
\hline $\mathbf{K}$ & 7200 \\
\hline La & $<0.02$ \\
\hline $\mathbf{L i}$ & $<0.7$ \\
\hline $\mathbf{L u}$ & $<0.02$ \\
\hline Mg & 800 \\
\hline Mn & 16 \\
\hline Mo & $<0.02$ \\
\hline $\mathbf{N a}$ & 1800 \\
\hline Nb & $<0.02$ \\
\hline Nd & $<0.02$ \\
\hline $\mathbf{N i}$ & $<0.2$ \\
\hline Os & $<0.02$ \\
\hline $\mathbf{P b}$ & $<0.2$ \\
\hline Pd & $<0.02$ \\
\hline Pr & $<0.02$ \\
\hline $\mathbf{P t}$ & $<0.2$ \\
\hline
\end{tabular}

50862

Fish Ovary

Purple 2009

$<0.02$

$<420$

0.4

$<0.02$

2.0

0.02

0.06

380

1700

$<0.02$

$<0.02$

0.07

2.0

$<0.02$

3.00

$<0.02$

$<0.02$

$<0.02$

$<2$

$<2$

$<0.02$

$<0.02$

$<0.02$

$<0.02$

$<0.02$

$<0.02$

7100

$<0.02$

$<0.7$

$<0.02$

740

12

$<0.02$

1600

$<0.02$

$<0.02$

$<0.2$

$<0.02$

$<0.2$

$<0.02$

$<0.02$

$<0.2$
50863

Fish Ovary

[Purple] 2006

$$
\begin{array}{r}
<0.02 \\
<420 \\
0.2 \\
<0.02 \\
2.0 \\
<0.02 \\
<0.02 \\
230 \\
1300 \\
<0.02 \\
<0.02 \\
0.10 \\
2.0 \\
<0.02 \\
3.0 \\
<0.02 \\
<0.02 \\
<0.02 \\
<2 \\
<2 \\
<0.02 \\
<0.02 \\
<0.02 \\
<0.02 \\
<0.02 \\
<0.02 \\
7800 \\
<0.02 \\
<0.7 \\
<0.02 \\
\quad 750 \\
14 \\
<0.02 \\
1900 \\
<0.02 \\
<0.02 \\
<0.2 \\
<0.02 \\
<0.2 \\
<0.02 \\
<0.02 \\
<0.2
\end{array}
$$


Table S1. Concentrations ( $\mu \mathrm{g} / \mathrm{g}$ dry wt) of total recoverable elements in whole fish from Eufaula Lake, Oklahoma, determined by ICP-MS semi-quantitative scan. (continued)

Rb

Re

Ru

Sb

Se

Sm

Sn

$\mathrm{Sr}$

Ta

Tb

Te

Ti

TI

Tm

U

V

W

Y

Yb

Zn

$\mathrm{Zr}$
1.0

$<0.02$

$<0.02$

$<0.02$

4.0

$<0.02$

$<0.02$

4.0

0.1

$<0.02$

$<0.02$

22

$<0.02$

$<0.02$

$<0.02$

0.1

$<0.02$

$<0.02$

$<0.02$

81
2.0

$<0.02$

$<0.02$

$<0.02$

3.0

$<0.02$

$<0.02$

6.0

0.1

$<0.02$

$<0.02$

27

$<0.02$

$<0.02$

$<0.02$

0.2

$<0.02$

$<0.02$

$<0.02$

85
1.0

$<0.02$

$<0.02$

$<0.02$

3.0

$<0.02$

$<0.02$

4.0

0.03

$<0.02$

$<0.02$

26

$<0.02$

$<0.02$

$<0.02$

0.3

$<0.02$

$<0.02$

$<0.02$

87

0.3 
Table S2. Concentrations ( $\mathrm{ng} / \mathrm{g}$ wet wt) of polychlorinated biphenyls, polybrominad diphenylethers, and persistent organochlorine pesticides in whole fish from Eufaula Lake, Oklahoma, determined by GC-ECD.

Sample

\begin{tabular}{rrr} 
PB013112 & Eufaula BlueCatfish & Eufaula BlueCatfish Female \\
& Male & \\
Procedural & Male & (Purple) \\
Blank & whole fish & whole fish \\
\hline
\end{tabular}

Percent Lipid

5.04

Total PCBs (146 congeners)

Total PBDEs (9 congeners)

$<1$

80

23

Pentachlorobenzene

$<0.1$

0.2

$<0.1$

A-BHC

$<0.1$

$<0.1$

0.1

B-BHC

$<0.1$

HCB

$<0.1$

$<0.1$

PCA

$<0.1$

0.3

0.3

$<0.1$

Lindane

$<0.1$

D-BHC

0.1

Heptachlor

$<0.1$

Aldrin

$<0.1$

Dacthal

$<0.1$

Heptachlor Epoxide

0.1

Oxychlordane

$<0.1$

T-Chlordane

0.1

o,p'-DDE

$<0.1$

Endosulfan I

$<0.1$

C-Chlordane

0.1

T-Nonachlor

$<0.1$

Dieldrin

$<0.1$

$p, p^{\prime}-$ DDE

1.9

0.3

0.7

0.2

0.2

$<0.1$

$<0.1$

$<0.1$

$<0.1$

$<0.1$

$<0.1$

o,p'-DDD

$<0.1$

Endrin

Endosulfan II

$<0.1$

$<0.1$

Endrin Aldehyde

1.0

0.3

0.2

0.5

0.6

0.2

0.3

0.8

2.4

0.2

$<0.1$

$<0.1$

$<0.1$

4.6

3.5

5.8

1.1

2.6

128

$<0.1$

0.6

$<0.1$

$<0.1$

$<0.1$

0.1

0.6

p,p'-DDD

0.4

C-Nonachlor

0.3

o,p'-DDT

$<0.1$

Endosulfate

$<0.1$

p,p'-DDT

$<0.1$

$<0.1$

Endrin Ketone

0.1

Methoxychlor

$<0.1$

9.5

3.7

$<0.1$

0.1

1.1

$<0.1$

$<0.1$

Mirex

$<0.1$ 
Table S3. Blue Catfish histology from Eufaula Lake, Okla. And the

Missouri River, Missouri.

\begin{tabular}{|c|c|c|c|c|c|c|c|c|c|c|}
\hline $\begin{array}{l}\text { Sample } \\
\text { ID }\end{array}$ & Capture date & Collected by & $\begin{array}{l}\text { Weight } \\
\text { (g) }\end{array}$ & $\begin{array}{c}\text { Length } \\
(\mathrm{mm})\end{array}$ & $\begin{array}{c}\text { Gonad } \\
\text { (g) }\end{array}$ & GSI & Sex & Comments & Location & Histology \\
\hline $\mathrm{BC} \# 1$ & May 25,2007 & $\begin{array}{l}\text { Connor State } \\
\text { University }\end{array}$ & 2321 & 622 & 198 & 9.33 & $\mathrm{~F}$ & yellow eggs & $\begin{array}{l}\text { East Bluff, north } \\
\text { side of Hwy } 150 \\
\text { bridge }\end{array}$ & $\begin{array}{l}\text { normal, spent, very thick OW, POFs, } \\
\text { some PNOs, some mature oocytes, } \\
\text { some may be atretic or poor } \\
\text { preservation. }\end{array}$ \\
\hline $\mathrm{BC} \# 2$ & May 25, 2007 & $\begin{array}{l}\text { Connor State } \\
\text { University }\end{array}$ & 1950 & 592 & 28 & 1.46 & $\mathrm{~F}$ & purple eggs & $\begin{array}{l}\text { northwest side of } \\
\text { Hwy } 150 \text { Bridge }\end{array}$ & $\begin{array}{l}\text { normal, spent, very thick OW, POFs, } \\
\text { some PNOs and CAOs present, } \\
\text { some may be atretic or poor } \\
\text { preservation. }\end{array}$ \\
\hline $\mathrm{BC} \# 3$ & May 25, 2007 & $\begin{array}{l}\text { Connor State } \\
\text { University }\end{array}$ & 3084 & 650 & 28 & 0.92 & $\mathrm{~F}$ & purple eggs & $\begin{array}{l}\text { northwest side of } \\
\text { Hwy } 150 \text { Bridge }\end{array}$ & $\begin{array}{l}\text { normal, spent, very thick OW, POFs, } \\
\text { some PNOs and CAOs present, } \\
\text { some may be atretic or poor } \\
\text { preservation. }\end{array}$ \\
\hline $\mathrm{BC} \# 4$ & May 25, 2007 & $\begin{array}{l}\text { Connor State } \\
\text { University }\end{array}$ & 5498 & 770 & no data & & $\mathrm{M}$ & & $\begin{array}{l}\text { northwest side of } \\
\text { Hwy } 150 \text { Bridge }\end{array}$ & no data. \\
\hline $\mathrm{BC} \# 5$ & May 25, 2007 & $\begin{array}{l}\text { Connor State } \\
\text { University }\end{array}$ & 1678 & 551 & 14 & 0.84 & $\mathrm{~F}$ & purple eggs & $\begin{array}{l}\text { North } \quad \text { Canadian } \\
\text { River } \\
\text { approx. } 0.5 \text { miles } \\
\text { from Eufaula Lake }\end{array}$ & $\begin{array}{l}\text { normal, spent, very thick OW, POFs, } \\
\text { some PNOs and CAOs present, } \\
\text { some may be atretic or poor } \\
\text { preservation. }\end{array}$ \\
\hline $\mathrm{BC} \# 7$ & May 25, 2007 & $\begin{array}{l}\text { Connor State } \\
\text { University }\end{array}$ & 1134 & 485 & 182 & 19.12 & $\mathrm{~F}$ & yellow eggs & $\begin{array}{l}\text { Cove north of Hwy } \\
266 \text { bridge, } \\
\text { Gentry Creek area }\end{array}$ & normal, mature oocytes. \\
\hline $\mathrm{BC} \# 8$ & May 25, 2007 & $\begin{array}{l}\text { Connor State } \\
\text { University }\end{array}$ & 1905 & 602 & 60 & 3.25 & $\mathrm{~F}$ & purple eggs & $\begin{array}{l}\text { Along Southwest } \\
\text { riprap, I-40 bridge }\end{array}$ & $\begin{array}{l}\text { normal, spent, very thick OW, POFs, } \\
\text { PNOs present, } \\
\text { some may be atretic or poor } \\
\text { preservation. }\end{array}$ \\
\hline $\mathrm{BC} \# 9$ & May 25, 2007 & $\begin{array}{l}\text { Connor State } \\
\text { University }\end{array}$ & 1089 & 503 & 70 & 6.87 & $\mathrm{~F}$ & purple eggs & $\begin{array}{l}\text { Along Southwest } \\
\text { riprap, I-40 bridge }\end{array}$ & $\begin{array}{l}\text { normal, spent, OW not as thick as } \\
(\# 8) \text {, POFs, some atretic mature } \\
\text { oocytes, PNOs present, some may be } \\
\text { atretic or poor preservation. }\end{array}$ \\
\hline $\mathrm{BC} \# 10$ & May 25, 2007 & $\begin{array}{l}\text { Connor State } \\
\text { University }\end{array}$ & 4128 & 724 & 28 & 0.68 & $\mathrm{~F}$ & purple eggs & $\begin{array}{l}\text { Cove, Sheppard } \\
\text { Estates \#2, } \\
\text { southwest of } \mathrm{I}-40 \\
\text { bridge }\end{array}$ & $\begin{array}{l}\text { normal, spent, very thick OW, POFs, } \\
\text { PNOs and a few CAOs present, } \\
\text { some may be atretic or poor } \\
\text { preservation. }\end{array}$ \\
\hline BC \#11 & May 25, 2007 & $\begin{array}{l}\text { Connor State } \\
\text { University }\end{array}$ & 1842 & 549 & 31 & 1.71 & $\mathrm{~F}$ & purple eggs & $\begin{array}{ll}\text { Coal Creek } & \text { near } \\
\text { confluence } & \\
\text { with Deep } & \text { Fork } \\
\text { River } & \end{array}$ & $\begin{array}{l}\text { normal, spent, very thick OW, POFs, } \\
\text { CAOs present, } \\
\text { some may be atretic or poor } \\
\text { preservation. }\end{array}$ \\
\hline BC \#12 & May 25, 2007 & $\begin{array}{l}\text { Connor State } \\
\text { University }\end{array}$ & 898 & 460 & 11 & 1.24 & $\mathrm{~F}$ & purple eggs & $\begin{array}{ll}\text { Coal Creek } & \text { near } \\
\text { confluence } & \\
\text { with Deep } & \text { Fork } \\
\text { River } & \end{array}$ & $\begin{array}{l}\text { normal, spent, very thick OW, } \mathrm{POFs} \text {, } \\
\text { PNOs present, some may be atretic } \\
\text { or poor preservation. }\end{array}$ \\
\hline BC \#13 & May 25, 2007 & $\begin{array}{l}\text { Connor State } \\
\text { University }\end{array}$ & 1628 & 569 & no data & & $\mathrm{F}$ & yellow eggs & $\begin{array}{l}\text { Eufaula Lake near } \\
\text { mouth } \\
\text { of South Canadian } \\
\text { River }\end{array}$ & normal, mature oocytes. \\
\hline $\mathrm{BC}$ & April 29, 2007 & $\begin{array}{l}\text { unidentified } \\
\text { fisher }\end{array}$ & no data & no data & no data & & $\mathrm{F}$ & yellow eggs & No information & normal, vitellogenic oocytes. \\
\hline $\mathrm{BC}$ & May 9, 2007 & $\begin{array}{l}\text { unidentified } \\
\text { fisher }\end{array}$ & no data & no data & no data & & $\mathrm{F}$ & yellow eggs & No information & $\begin{array}{l}\text { normal, mature oocytes, a few atretic } \\
\text { or poor preservation. }\end{array}$ \\
\hline
\end{tabular}




\begin{tabular}{|c|c|c|c|c|c|c|c|c|c|}
\hline Fish 1 & March, 2007 & $\begin{array}{l}\text { unidentified } \\
\text { fisher }\end{array}$ & no data & no data & no data & $\mathrm{F}$ & immature & $\begin{array}{l}\mathrm{N} \text { of Hwy } 150 \\
\text { Eufaula Lake }\end{array}$ & normal, PNOs. \\
\hline Fish 2 & March, 2007 & $\begin{array}{l}\text { unidentified } \\
\text { fisher }\end{array}$ & no data & no data & no data & I & gonad & $\begin{array}{l}\mathrm{N} \text { of Hwy } 150 \\
\text { Eufaula Lake }\end{array}$ & \\
\hline $\mathrm{BC}$ & June 23, 2011 & $\begin{array}{l}\text { US Fish and } \\
\text { Wildlife } \\
\text { Service, } \\
\text { Missouri }\end{array}$ & no data & no data & no data & $\mathrm{F}$ & yellow eggs & $\begin{array}{l}\text { Missouri River near } \\
\text { Boonville, Missouri }\end{array}$ & \\
\hline
\end{tabular}

OW is ovarian wall

POF is post-ovulatory follicle

PNO is perinucleolar oocyte

$\mathrm{CAO}$ is cortical alveolar oocyte 


\section{Stentorin and Related Phenanthroperylene Quinones Identified in Plants and Animals}

Stentorin has not been well studied. Hypericin, a structurally similar compound, is the most thoroughly investigated phenanthroperylene quinone. Other phenanthroperylene quinones in plants (e.g., St. John's wort, Hypericum perforatum; buckwheat, Fagopyrum sp.), crinoids (sea lilies and other crinoid species), and in other heterotrich ciliates function as ingestion deterrents. Consumption of Hypericum sp. and Fagopyrin sp. by grazing animals can cause photohemolysis. 
Table S4. Related phenanthroperylene quinones identified in plants and animals.

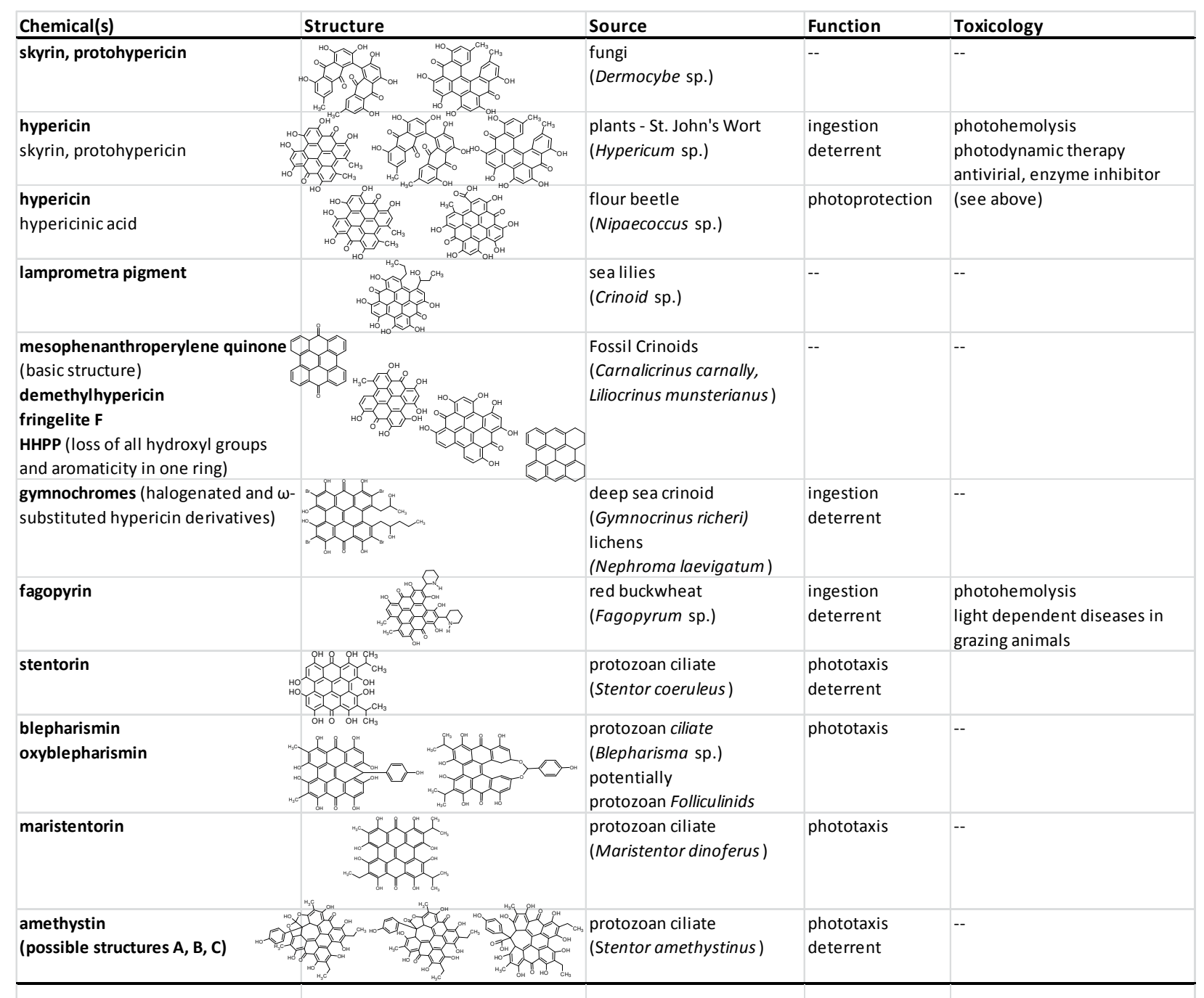


Table S5. Estimation of S. coeruleus-equivalents consumed by Eufaula Lake 2006-female catfish.

\begin{tabular}{|c|c|c|c|c|c|}
\hline & & & \multirow[b]{2}{*}{ Stentors } & \multicolumn{2}{|c|}{ Range of Values } \\
\hline & & & & Low & High \\
\hline & & & & & \\
\hline & & & Number of stentors per container (stentor number, $\mathrm{N}$ ): & 500 & 200 \\
\hline & & & & & \\
\hline & & & Number of Containers (container number, C): & 13 & 13 \\
\hline & & & & & \\
\hline & & & Final volume ( $\mathrm{Vfs})$ : & 5 & 5 \\
\hline & & & & & \\
\hline & & & Dilution factor (Ds): & 10 & 20 \\
\hline & & & & & \\
\hline & & & Fluoresecence (ex 365 nm em 605 nm LU, Fs): & 170 & 380 \\
\hline & & & & & \\
\hline & & & Catfish & & \\
\hline & & & & & \\
\hline & & & Mass of ovaries with eggs ( $\mathrm{g}, \mathrm{Mo})$ : & 10 & 10 \\
\hline & & & & & \\
\hline & & & Final volume ( $\mathrm{ml}, \mathrm{Vfo})$ : & 5 & 5 \\
\hline & & & & & \\
\hline & & & Dilution factor (Do): & 10 & 10 \\
\hline & & & & & \\
\hline & & & Fluorescence (ex 365 nm em 605 nm LU, Fo): & 98 & 150 \\
\hline & & & & & \\
\hline & & & Percent lipid in ovaries with eggs (\%, Lo): & 25 & 50 \\
\hline & & & & & \\
\hline & & & Percent lipid in fish (\%, Lf): & 5 & 10 \\
\hline & & & & & \\
\hline & & & Mass $f$ fish ( $g, M f)$ : & 1000 & 2500 \\
\hline total $\mathrm{f}$ & fluorescenc & ce/stentor & $=$ (total fluorescence of stentors) / (number of stentors) & & \\
\hline & & $=(\mathrm{Fs} * \mathrm{Ds}$ & $* V f s) /(C * N)$ & $1 \mathrm{E}+00$ & $1 \mathrm{E}+01$ \\
\hline & & & & & \\
\hline & tal fluoresc & cence/fish & $=($ total fluorescence per gram ovary $) *($ ratio of average lipid in fish $t$ & n ovary) " & of fish) \\
\hline & & $=((\mathrm{Fo} * \mathrm{D}$ & o* Vfo $) /($ Mo $)) *($ Lf / Lo ) * (Mf) & $1 \mathrm{E}+05$ & $4 \mathrm{E}+05$ \\
\hline Ste & entors/fish & $=($ total flu & orescence / fish) / (total fluorescence / stentor) & & \\
\hline & & $=[(\mathrm{Fo} * \mathrm{D}$ & $0 * V f o) /(M o)) *(L f / L o) *(M f)] /[(F s * D s * V f s) /(C * N)]$ & 7E+04 & $3 E+04$ \\
\hline & & & & & \\
\hline & & & & & \\
\hline & & & Stentor-Equivalents (n/fish): & $7 E+04$ & $3 E+04$ \\
\hline Fluoresce & nce values & from: & & & \\
\hline & $2009-08-12$ & 2 Eufaula $A$ & bsorption-Fluorescence-MSn.xIsx & & \\
\hline & $2012-11-19$ & 9 S coerule & us Fluorescence and Extraction Summary.docx & & \\
\hline
\end{tabular}




\section{Bioaccumulation of Stentorin in Eufaula Lake (Extended Text)}

We suspect that conditions in 2006 were favorable for an S. coeruleus bloom in the northern arm of EL due to excessive organic and nutrient loading (1996-2000), especially after the upstream sewage spill of April-June 2000. Based on relative fluorescence intensities and estimated dilution factors, we estimate that about $10^{4}-10^{5}$ individuals (about $0.1-1.0 \mathrm{~g}$ ) of $S$. coeruleus would have had to be consumed by a typical young female catfish (with eggs) to produce the fluorescence observed in the EL fish. There are significant uncertainties (e.g., S. coeruleus pigmentation; fish size and lipid and lipoprotein content; metabolism, depuration, and timing relative to egg development), that make better estimations impracticable. However, and although $S$. coeruleus is large relative to other unicellular organisms, it is not likely that it was directly targeted for consumption by adult catfish. Either incidental ingestion of stentors (with detritus or entrained within another organism) or (more likely) stentorin bioaccumulation via the food web seem more plausible. Blue catfish are opportunistic omnivores, but large individuals (>300 mm TL) are mainly piscivorous. Gizzard shad (Dorosoma cepedianum) and threadfin shad (D. petenense), both of which are present in EL, ${ }^{1}$ are among the most heavily consumed species $^{2-4}$ by catfish. Gizzard shad are omnivorous planktivores ${ }^{5}$ that spawn in the spring in Oklahoma impoundments; larvae typically appear in May followed by transformed juveniles in June. $^{6}$ Gizzard shad more than 2 years old, which primarily eat phytoplankton, are too large to be eaten by most freshwater fish, ${ }^{4}$ but juveniles prey more heavily on zooplankton (including ciliates) $)^{5,7}$ and are heavily consumed by catfish. Threadfin shad remain small enough to be eaten by catfish and eat zooplankton throughout their life. ${ }^{4}$ Either or both of these high-lipid species represent plausible routes of stentorin accumulation by catfish. Any combination of direct 
consumption of $S$. coeruleus, indirect consumption of stentors associated with detritus or entrained within zooplankton, or prior bioconcentration or bioaccumulation of stentorin by the zooplankton eaten by the planktivorous fish could have preceded accumulation by the catfish. Stentorin, like other related phenanthroperylene quinones, is not readily metabolized, and is likely to persist through the food web sufficiently for some bioaccumulation to occur. Bioaccumulation would be followed by subsequent depuration and growth dilution, as indicated by the diminishing observations of 'purple' eggs over several years following the initial peak in reported incidences.

From 1995 through 2008, the ovaries of 1,819 female fish of 19 species (including blue catfish) from US waters (including EL) were examined for gross visible and histopathological abnormalities, ${ }^{8}$ and references therein; no "purple" ovaries were reported, nor have any been reported in the literature since-despite large numbers of recent papers on gonadal abnormalities in fish. The rarity with which the condition seems to occur indicates either that $S$. coeruleus blooms or the consumption of stentors in large numbers by aquatic organisms occur infrequently. Conversely, we also detected orange-red fluorescence in normal EL ovaries and (to a lesser extent) MR ovaries, indicating that stentorin accumulation is common and that discolored ovaries occur only as a result of extraordinarily high concentrations.

The discolored ovaries also contained extractable yellow-green fluorescent component(s) that spectroscopically corresponded with extracts from normal EL ovaries. The yellow-green component(s) were not evident in MR ovaries, however (Figure 2). Together, these findings indicate dietary overlap between the two groups of EL female catfish, the major difference being the much greater stentorin concentration in ovaries of affected fish. Conversely, the fluorescence 
of MR catfish ovaries indicates different food sources much reduced in both stentorin and the unidentified yellow-green component(s) present in EL catfish.

In summary, stentorin is unique to S. coeruleus; consequently, we suspect that the stentors, their detritum, or other food web prey that previously consumed stentors or detritum is the initial step in stentorin bioaccumulation by fish. S. coeruleus flourishes in waters receiving organic pollution. Conditions favorable for S. coeruleus were likely present following the 2000 WWTP release and subsequent (2005-2006) industrial effluent releases into the Deep Fork and North Canadian rivers, which feed the highly eutrophic northern arm of EL. Discolored egg occurrence peaked in 2006-2007, decreased in subsequent years, and there have been no recent reports, all of which are consistent with a stentor bloom in response to an episodic pollution event. Stentorin is a highly lipophilic biogenic compound that appears to accumulate in fish eggs and other lipid-rich tissues. Our limited analyses of normal EL and MR fish indicate that stentorin accumulation may be common in fish, with high concentrations occurring only when hydrologic and ecological conditions are favorable for an S. coeruleus bloom. The frequency, magnitude, extent, and potential toxicological significance of such blooms and of stentorin bioaccumulation in fish and higher trophic level organisms (including wildlife and humans) are unknown.

Although we demonstrated feeding on $S$. coeruleus and stentorin uptake by larval medaka, we did not maintain the fish to maturity. Completing Koch's postulates ${ }^{9}$ would require laboratory studies that include HPLC-MS confirmation of stentorin accumulation in eggs of medaka or other species and would demonstrate the proposed sequence of events that led to discolored eggs. Additional future studies could include: (1) documenting the viability (or not) of eggs containing accumulated stentorin, which would provide information regarding potentially unrecognized ecological consequences resulting from episodic organic pollution events; (2) determining the 
distribution and stability of stentorin in fish and assessing its toxicity; (3) determining the temporal and geographic distribution of stentorin in fish as an indicator of exposure to organic enrichment, as a tracer for locating pollution sources, and as a marker for episodic pollution events; and (4) determining the identities and significance of the yellow-green and blue fluorescent compounds isolated from catfish eggs and ovaries.

(1) Bowen, D. Eufaula Lake 5-Year Management Plan; Oklahoma Department of Wildlife Conservation, 2008; p. 38.

(2) Edds, D. Resource use by large catfishes in a reservoir: is there evidence for interactive segregation and innate differences? J. Fish Biol. 2002, 60, 739-750.

(3) Graham, K. A review of the biology and management of blue catfish. Catfish 2000 Proc. Int. ictalurid ... 1999, 24, 37-49.

(4) Pflieger, W. L. The Fishes of Missouri; Missouri Department of Conservation, 1997; p. 372.

(5) Schaus, M.; Vanni, M.; Wissing, T. Biomass-dependent diet shifts in omnivorous gizzard shad: implications for growth, food web, and ecosystem effects. Trans. Am. Fish. Soc. 2002, 131, 40-54.

(6) Downey, P.; Toetz, D. Distribution of larval gizzard shad (Dorosoma cepedianum) in Lake Carl Blackwell, Oklahoma. Am. Midl. Nat. 1983, 109, 23-33.

(7) Kutkuhn, J. H. Utilization of Plankton by Juvenile Gizzard Shad in a Shallow Prairie Lake. Trans. Am. Fish. Soc. 1958, 87, 37-41. 
(8) Hinck, J. E.; Blazer, V. S.; Schmitt, C. J.; Papoulias, D. M.; Tillitt, D. E. Widespread occurrence of intersex in black basses (Micropterus spp.) from U.S. rivers, 1995-2004. Aquat. Toxicol. 2009, 95, 60-70.

(9) Suter II, G. W. Ecological Risk Assessment, Second Edition; CRC Press, 2006; p. 680. 